\title{
ESTIMATING ENERGY AND COST SAVINGS AND EMISSIONS REDUCTIONS FOR THE STATE ENERGY PROGRAM BASED ON ENUMERATION INDICATORS DATA
}

Martin Schweitzer

Donald W. Jones

Linda G. Berry

Bruce E. Tonn 


\section{ESTIMATING ENERGY AND COST SAVINGS AND EMISSIONS REDUCTIONS FOR THE STATE ENERGY PROGRAM BASED ON ENUMERATION INDICATORS DATA}

Martin Schweitzer, Donald W. Jones, Linda G. Berry, and Bruce E. Tonn

Date Published: January 2003

Prepared for

U.S. Department of Energy

Office of the Weatherization and Intergovernmental Program

Budget Activity Number EC 1501000

Prepared by

OAK RIDGE NATIONAL LABORATORY

Oak Ridge, Tennessee 37831

managed by

UT-BATTELLE, LLC

for the

U.S. DEPARTMENT OF ENERGY

under contract DE-AC05-00OR22725 


\section{DOCUMENT AVAILABILITY}

Reports produced after January 1, 1996, are generally available free via the U.S. Department of Energy (DOE) Information Bridge.

Web site http://www.osti.gov/bridge

Reports produced before January 1, 1996, may be purchased by members of the public from the following source.

National Technical Information Service

5285 Port Royal Road

Springfield, VA 22161

Telephone 703-605-6000 (1-800-553-6847)

TDD 703-487-4639

Fax 703-605-6900

E-mailinfo@ntis.fedworld.gov

Web site http://www.ntis.gov/support/ordernowabout.htm

Reports are available to DOE employees, DOE contractors, Energy Technology Data Exchange (ETDE) representatives, and International Nuclear Information System (INIS) representatives from the following source.

Office of Scientific and Technical Information

P.O. Box 62

Oak Ridge, TN 37831

Telephone 865-576-8401

Fax 865-576-5728

E-mail reports@adonis.osti.gov

Web site http://www.osti.gov/contact.html

This report was prepared as an account of work sponsored by an agency of the United States Government. Neither the United States Government nor any agency thereof, nor any of their employees, makes any warranty, express or implied, or assumes any legal liability or responsibility for the accuracy, completeness, or usefulness of any information, apparatus, product, or process disclosed, or represents that its use would not infringe privately owned rights. Reference herein to any specific commercial product, process, or service by trade name, trademark, manufacturer, or otherwise, does not necessarily constitute or imply its endorsement, recommendation, or favoring by the United States Government or any agency thereof. The views and opinions of authors expressed herein do not necessarily state or reflect those of the United States Government or any agency thereof. 


\section{TABLE OF CONTENTS}

Page

LIST OF FIGURES . V

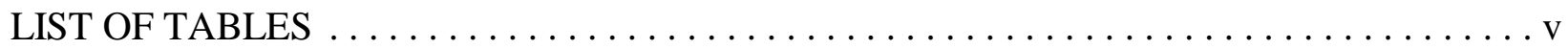

EXECUTIVE SUMMARY $\ldots \ldots \ldots \ldots \ldots \ldots \ldots \ldots \ldots \ldots \ldots \ldots \ldots \ldots \ldots \ldots$

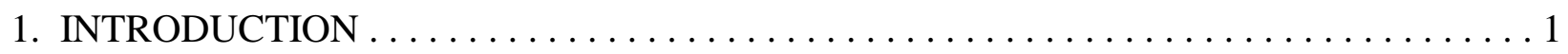

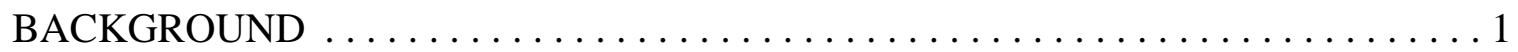

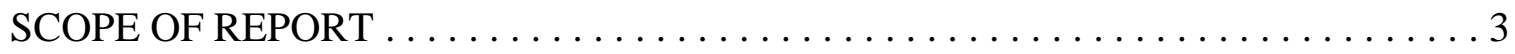

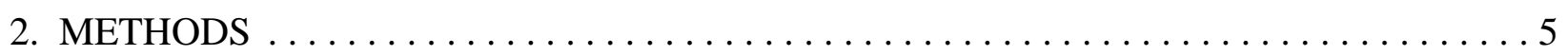

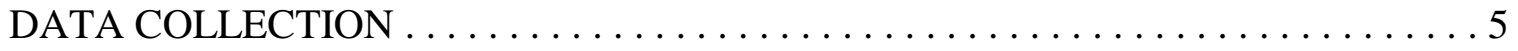

CALCULATING SAVINGS AND EMISSIONS REDUCTIONS $\ldots \ldots \ldots \ldots \ldots \ldots 7$

3. DESCRIPTION OF RESPONDING STATES $\ldots \ldots \ldots \ldots \ldots \ldots \ldots \ldots \ldots \ldots$

KEY STATE CHARACTERISTICS . . . . . . . . . . . . . . . 9

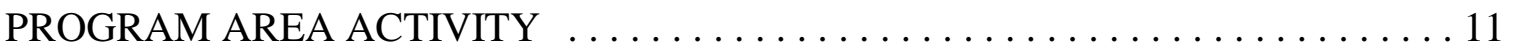

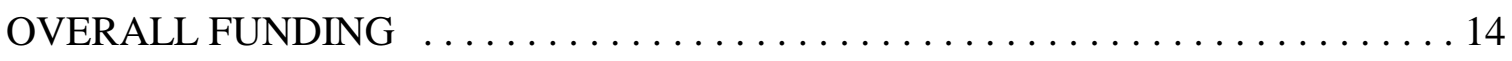

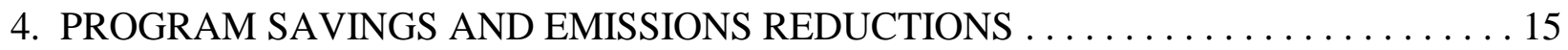

SAVINGS AND EMISSIONS REDUCTIONS BY PROGRAM AREA . . . . . . 15

TOTAL SAVINGS AND EMISSIONS REDUCTIONS $\ldots \ldots \ldots \ldots \ldots \ldots \ldots$

5. SUMMARY AND CONCLUSIONS $\ldots \ldots \ldots \ldots \ldots \ldots \ldots \ldots \ldots \ldots \ldots \ldots$

SUMMARY OF FINDINGS FROM RESPONDING STATES . . . . . . . . . . . 19

EXTRAPOLATION OF FINDINGS TO STATE ENERGY

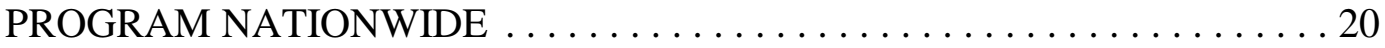

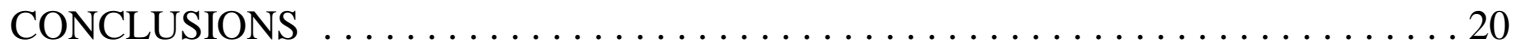

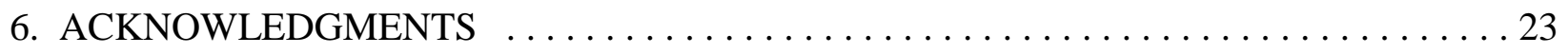

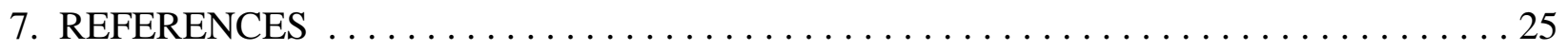

APPENDIX A. DEVELOPMENT OF ENERGY-SAVINGS COEFFICIENTS . . . . . . . . 29

APPENDIX B. SAVINGS CALCULATIONS $\ldots \ldots \ldots \ldots \ldots \ldots \ldots \ldots \ldots \ldots \ldots \ldots$

APPENDIX C. METHOD FOR CALCULATING EMISSIONS REDUCTIONS . . . . . . 55 



\section{LIST OF FIGURES}

Page

Figure ES.1. Estimated annual energy savings, by program area. ............. xi

Figure ES.2. Estimated annual energy savings per dollar of funding for program areas where savings are quantified $\ldots \ldots \ldots \ldots \ldots \ldots \ldots \ldots \ldots \ldots \ldots \ldots \ldots \ldots$ xii

Figure ES.3. Estimated annual cost savings per dollar of funding for program areas where savings are quantified $\ldots \ldots \ldots \ldots \ldots \ldots \ldots \ldots \ldots \ldots \ldots \ldots \ldots \ldots \ldots$

Figure 1. States providing enumeration indicators data. $\ldots \ldots \ldots \ldots \ldots \ldots \ldots \ldots$

\section{LIST OF TABLES}

Table ES.1. Program area funding and activity reported by responding states $\ldots \ldots \ldots \ldots$ ix

Table 1. Program areas covered by enumeration indicators $\ldots \ldots \ldots \ldots \ldots \ldots \ldots \ldots \ldots$

Table 2. Enumeration indicators for which per-unit savings

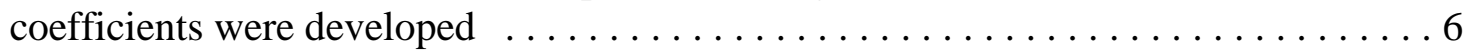

Table 3. Responding states: population and SEP funding as percent of total $\ldots \ldots \ldots \ldots 10$

Table 4. Number of states providing data for each program area $\ldots \ldots \ldots \ldots \ldots \ldots \ldots 11$

Table 5. Reported allocation of funds, by program area $\ldots \ldots \ldots \ldots \ldots \ldots \ldots \ldots \ldots$

Table 6. SEP funds, leveraged dollars, and total funding for responding states $\ldots \ldots \ldots \ldots 14$

Table 7. Estimated annual energy and cost savings, by program area . . . . . . . . . . 16

Table 8. Annual emissions reductions, by program area $\ldots \ldots \ldots \ldots \ldots \ldots \ldots \ldots \ldots \ldots \ldots$

Table 9. Estimated annual savings achieved in responding states per dollar of funding for program areas where savings are quantified $\ldots \ldots \ldots \ldots \ldots \ldots$

Table 10. Total annual energy and cost savings for responding states and entire nation . . . . 20

Table 11. Total annual emissions reductions for responding states and entire nation $\ldots \ldots \ldots 21$ 



\section{EXECUTIVE SUMMARY}

As part of an effort to produce metrics for quantifying the effects of the U.S. Department of Energy's (DOE's) State Energy Program (SEP), staff at Oak Ridge National Laboratory (ORNL) developed a classification scheme for describing the various state activities supported by SEP funds. This involved identifying a number of distinct program areas into which all of the various state SEP activities could be placed. Then, a set of "enumeration indicators" was developed to describe key activities within each of those areas. Although originally developed to count program activities, the enumeration indicators are used here as a basis for estimating the savings and emissions reductions achieved by the SEP. While there are additional benefits associated with the SEP, such as increased energy security and economic well-being, they are not addressed in this study.

The 20 program areas that are the focus of this study are listed below.

- Information Inquiries

- Mass Media

- School Education Programs

- Workshops/Training

- Retrofits

- Energy Audits

- Procurement of Energy-Efficient Products

- Technical Assistance

- Loans and Grants

- Codes and Standards

- Rating and Labeling

- Home Energy Rating Systems (HERS) and Energy-Efficiency Mortgages (EEMs)

- Incentives

- Interest Subsidies

- Alternative Fuels

- Planning

- Tax Credits

- Traffic Signals and Controls

- Research, Development, Demonstration, and Deployment (RDD\&D)

- Carpools/Vanpools 
All states, territories, and the District of Columbia were contacted in late 2001 and asked to provide "enumeration indicators" data describing their SEP activities for their most recent completed program year. The 20 states listed below responded by August 31, 2002, and the information that they provided serves as the basis for this report.

- Alabama

- Arkansas

- California

- Colorado

- Georgia

- Hawaii

- Idaho

- Iowa

- Minnesota

- Nebraska

- New York

- Ohio

- Oregon

- Rhode Island

- Tennessee

- Texas

- Washington

- West Virginia

- Wisconsin

- Wyoming

The 20 responding states are spread across the entire United States, both from east to west and from north to south. They include the three most populous states in the nation (California, Texas, and New York) as well as the least populous state (Wyoming). Together, they represent $45.6 \%$ of all funds allocated by SEP in 2000 (from formula grants and special project awards combined) and $49.6 \%$ of the entire United States population.

In combination, the 20 responding states reported receiving slightly more than $\$ 26$ million in SEP funds and over $\$ 119$ million in total funding, which includes both SEP and leveraged non-SEP monies. For each dollar of SEP funding spent on all program types, the states obtained $\$ 3.54$ from other sources. There was substantial variation among the responding states in how they calculated the amount of money leveraged, with some states reporting a much larger portion of their non-SEP funding than did others. Also, the System Benefits Charge (SBC) funds received by some states were very substantial but were not counted in this study. If all funding received by State Energy Offices was counted, the leveraging figure-and overall savings-would be much greater than reported here. The differences in state reporting practices, and the variety of funding sources that they utilize, suggest the need for a standard definition of leveraging, both for SEP and other DOE programs, which warrants additional future study. 
As shown in Table ES.1, three-fourths or more of the responding states conducted activities using SEP funds in the areas of Workshops/Training, Mass Media, Information Inquiries, Loans and Grants, Technical Assistance, Alternative Fuels, and Codes and Standards. On the other end of the scale, less than one-fourth of the responding states engaged in SEP-supported activities related to Traffic Signals and Controls, Tax Credits, Rating and

Table ES.1. Program area funding and activity reported by responding states

\begin{tabular}{|c|c|c|c|}
\hline $\begin{array}{r}\text { SEP fund } \\
\text { of total } \\
\text { reporte } \\
\text { prograr }\end{array}$ & $\begin{array}{l}\text { ing as percent } \\
\text { SEP funding } \\
\text { d for all } 20 \\
\mathrm{n} \text { areas }(\%)\end{array}$ & $\begin{array}{l}\text { Total funding (SEP }+ \\
\text { non-SEP) as percent of } \\
\text { total reported for all } 20 \\
\text { program areas }(\%)\end{array}$ & $\begin{array}{l}\text { Number of states } \\
\text { providing data }\end{array}$ \\
\hline Loans and Grants & 22.11 & 21.75 & 16 \\
\hline Codes and Standards & 18.89 & 7.29 & 15 \\
\hline Alternative Fuels & 17.38 & 20.23 & 16 \\
\hline Information Inquiries & 7.38 & 3.18 & 17 \\
\hline Technical Assistance & 6.40 & 9.66 & 16 \\
\hline Energy Audits & 5.37 & 3.84 & 12 \\
\hline Workshops/Training & 5.14 & 3.81 & 19 \\
\hline $\begin{array}{l}\text { Research, Development, Demonstration, } \\
\text { and Deployment (RDD\&D) }\end{array}$ & 4.86 & 4.77 & 13 \\
\hline Planning & 4.13 & 1.22 & 12 \\
\hline Mass Media & 3.03 & 6.95 & 18 \\
\hline School Education & 1.74 & 1.57 & 10 \\
\hline Retrofits & 1.31 & 1.67 & 12 \\
\hline HERS/EEMs & 1.20 & 12.36 & 5 \\
\hline Incentives & 0.54 & 0.31 & 5 \\
\hline Carpools/Vanpools & 0.36 & 0.23 & 2 \\
\hline Rating and Labeling & 0.06 & 0.01 & 2 \\
\hline Interest Subsidies & 0.05 & 0.34 & 2 \\
\hline Procurement & 0.05 & 0.33 & 6 \\
\hline Traffic Signals & 0 & 0.49 & 2 \\
\hline Tax Credits & 0 & 0.0 & 2 \\
\hline
\end{tabular}


Labeling, Carpools/Vanpools, and Interest Subsidies. The three most-heavily funded program areas (Loans and Grants, Codes and Standards, and Alternative Fuels) together accounted for over $58 \%$ of all SEP funding reported by the responding states and the top five (the previous three plus Information Inquiries and Technical Assistance) accounted for over $72 \%$ of SEP funding. Not surprisingly, those program areas receiving the largest share of SEP funding are also areas in which a majority of the responding states conducted activities.

For total funding (SEP plus non-SEP), Loans and Grants received the largest amount, followed by Alternative Fuels, HERS/EEMs, Technical Assistance, Codes and Standards, and Mass Media. The program areas with the lowest total funding were Tax Credits, Rating and Labeling, Carpools/Vanpools, Incentives, Procurement, Interest Subsidies, and Traffic Signals. This list of the most- and least-funded program areas is similar, but not identical, to the compilation presented above for SEP funding. Differences between the two lists are due to the fact that some program areas leveraged substantially more funds from non-SEP sources than did others.

Estimates of the savings achieved per SEP activity were developed by ORNL staff for selected enumeration indicators in 14 of the 20 program areas listed previously. Those savings coefficients were taken from recent evaluations that focus on the effects of various state energy efficiency and renewable energy programs as well as from previous ORNL research on the measurement of SEP outcomes. The per-unit savings estimates were multiplied by stateprovided information on the number of activities undertaken to calculate energy savings. Those energy-savings numbers were, in turn, multiplied by average energy prices to provide estimates of cost savings. Because the individual savings estimates generally were taken from a limited number of studies and are here applied broadly to the entire SEP, they must be treated as approximations of actual savings. Still, this study is the most rigorous and comprehensive study of the SEP undertaken to date, and the resulting savings numbers represent valid estimates of program accomplishments.

Figure ES.1 graphically illustrates the savings achieved by the responding states in the various program areas for which outcomes could be quantified. Approximately 85 percent of the total energy savings occurred in the top five program areas: Codes and Standards, Energy Audits, Rating and Labeling, Workshops and Training, and Incentives. Nearly all of the remaining energy savings came from the next three highest-saving program areas: Retrofits, Loans and Grants, and Technical Assistance. Because emissions reductions are calculated directly from energy savings, the relative magnitude of the reductions achieved in each program area are the same as for energy savings.

In all 14 program areas for which outcomes could be quantified, annual energy savings were estimated to be nearly 19,000,000 million source BTUs and cost savings were almost \$117 million. These estimates are likely to be low because they do not include savings estimates for one or more important enumeration indicators or energy-consuming sectors within some of those 14 areas, nor do they contain savings numbers for six other program areas where no savings coefficients could be developed. 


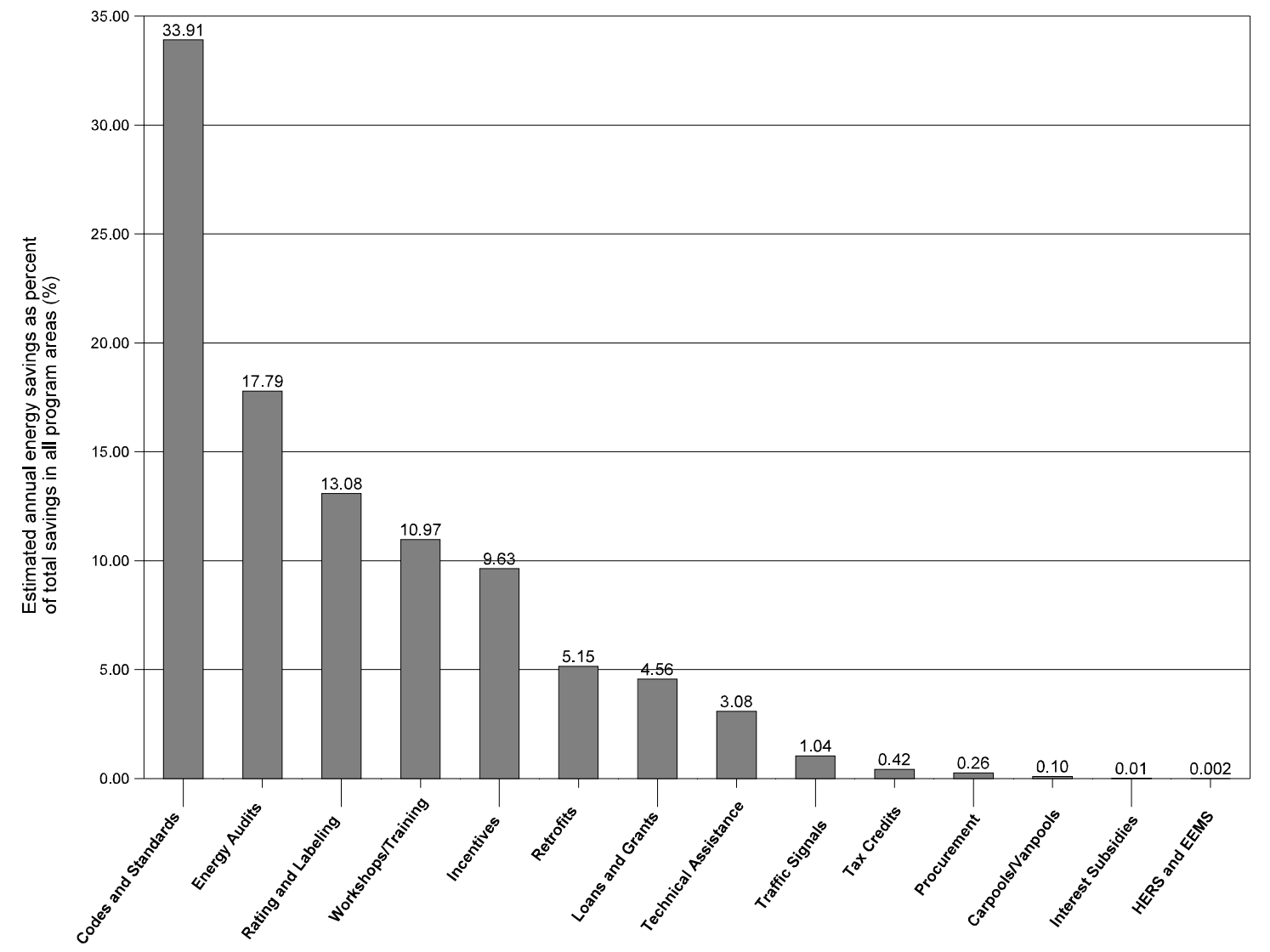

Figure ES.1. Estimated annual energy savings, by program area.

In the responding states, 1.17 million source BTUs and $\$ 7.23$ were saved annually for each dollar of SEP funds spent on programs for which savings could be quantified. This represents a payback period of only 0.14 years. For total reported funding (SEP plus leveraged non-SEP), each dollar allocated to those same program areas resulted in annual savings of 0.25 million source BTUs and \$1.58 (Figures ES.2 and ES.3). The payback period for this total investment is 0.63 years. And the annual savings reported here are expected to continue for many years to come.

Emissions reductions were calculated by multiplying the savings achieved within each program area by coefficients representing average emissions per million source BTUs for that program area for various types of substances. For all 14 program areas where savings could be quantified, carbon emissions were reduced by nearly 328,000 metric tons annually, $\mathrm{SO}_{2}$ 
emissions 


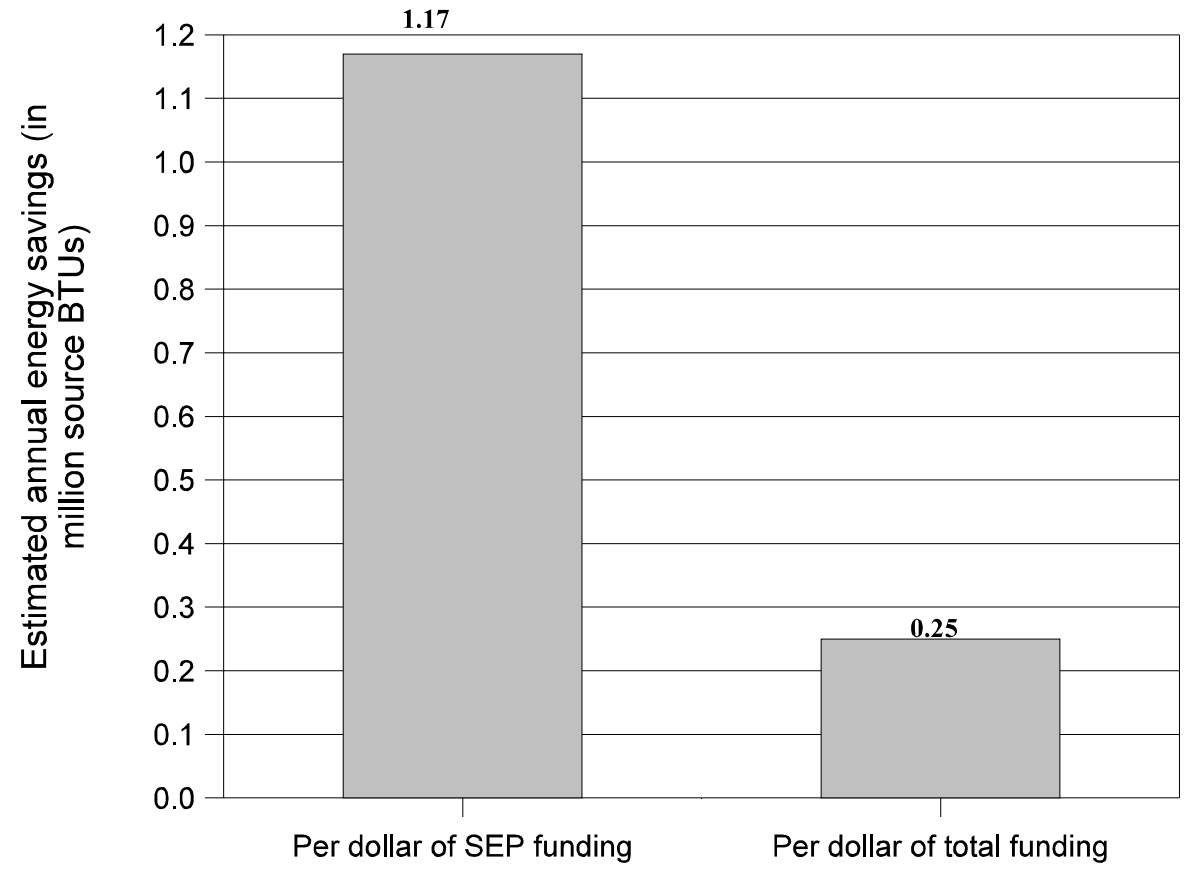

Figure ES.2. Estimated annual energy savings per dollar of funding for program areas where savings are quantified

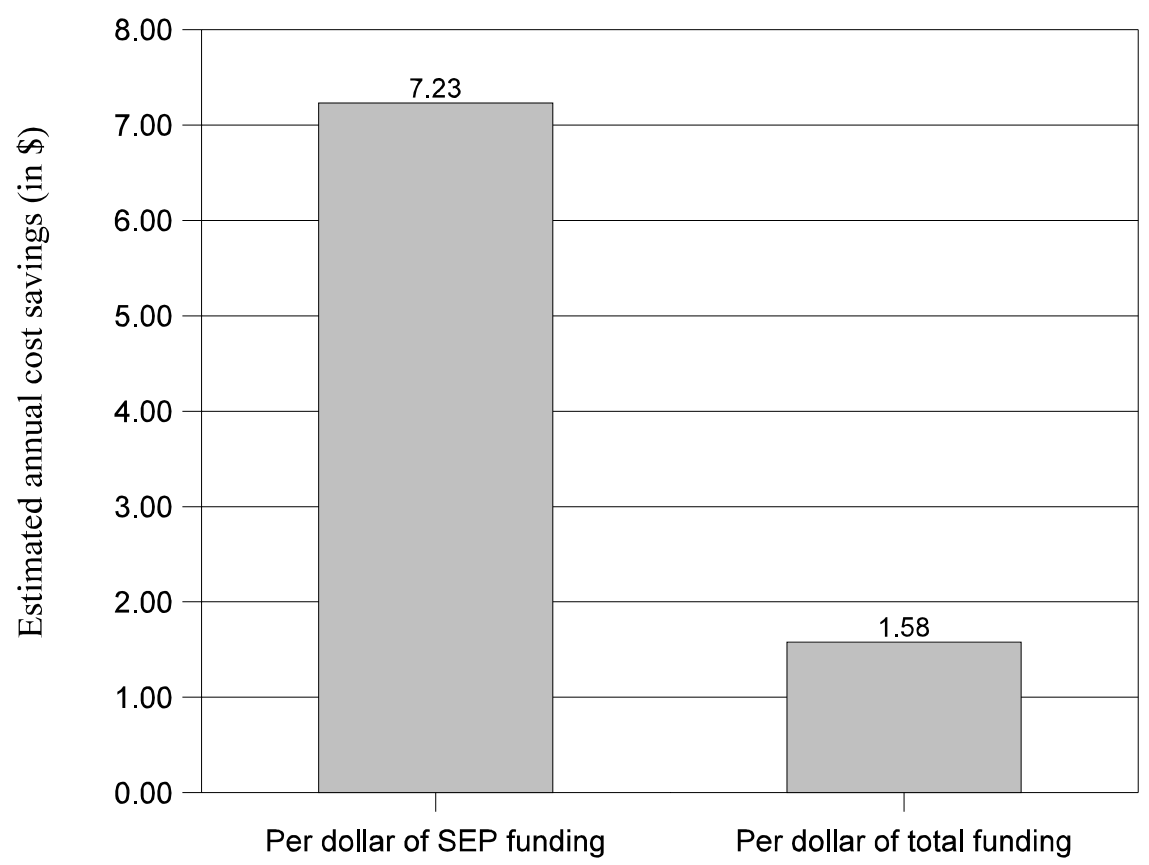

Figure ES.3. Estimated annual cost savings per dollar of funding for program areas where savings are quantified 
declined by almost 3,500 metric tons per year, annual emissions of $\mathrm{NO}_{\mathrm{x}}$ went down by over 2,6000 metric tons, yearly emissions of $\mathrm{CO}$ were reduced by almost 450 metric tons, and both VOCs and PM10 emissions declined by roughly 60 metric tons per year.

In addition, the SEP produces benefits of other kinds (e.g., security-related, economic) that were not quantified by this study. Had the full monetary value of all non-energy benefits been calculated, it is likely that the cost savings numbers presented above would have been considerably larger.

The savings and emissions reductions estimates for the responding states can be extrapolated to the nation as a whole based on the proportion of total SEP funding represented by the states that provided data. Since the 20 responding states, in combination, account for $45.6 \%$ of total SEP funding, energy and cost savings for this group can be multiplied by an adjustment factor of 2.19298 (the inverse of 0.456) to produce a defensible estimate of nationwide savings. Based on the savings estimates generated for the responding states, estimated annual energy and cost savings for the nation as a whole would be over 41,000,000 million source BTUs and $\$ 256$ million, respectively. Carbon emissions would be reduced by nearly 720,000 metric tons, while the emissions in the other five categories studied would be considerably smaller but still substantial.

The impressive savings and emissions reductions numbers, ratios of savings to funding, and payback periods presented above, while not precise, indicate that the SEP is operating effectively and is having a substantial positive impact on the nation's energy situation. 



\section{INTRODUCTION}

\section{BACKGROUND}

The U.S. Department of Energy's (DOE's) State Energy Program (SEP) was established in 1996 by merging two long-standing programs, the State Energy Conservation Program (SECP) and the Institutional Conservation Program (ICP), both of which had been in existence since 1976 (U.S. Department of Energy 2001a). The SEP provides financial and technical assistance for a wide variety of energy efficiency and renewable energy activities undertaken by the states, and the resources provided by DOE typically are augmented by money and in-kind assistance from a number of sources, including other federal agencies, state government, and the private sector. The states' SEP efforts include a number of mandatory activities, such as the establishment of lighting efficiency standards for public buildings, as well as a broad range of optional activities, such as the provision of energy audits and the development of integrated energy plans. The purpose of this report is to present estimates of the savings and emissions reductions achieved by the SEP during its most recent year of operation, based on information regarding program activities provided by the states themselves.

As part of an effort to produce metrics for quantifying the effects of the SEP, staff at Oak Ridge National Laboratory (ORNL) developed a classification scheme for describing the various state activities supported by SEP funds. This involved identifying a number of distinct program areas into which all of the various state SEP activities could be placed. Originally, 21 program areas were identified but one-Low-Income Weatherization-was dropped because no SEP funds were directly used to support those efforts. The 20 remaining program areas, which are the focus of this study, are shown in Table 1.

A set of "enumeration indicators" was developed to describe key activities within each of the 20 areas shown in Table 1 (Schweitzer et. al. 2002). In the terminology of the Government Performance and Results Act (GPRA), these enumeration indicators describe program "outputs," or key actions taken (e.g., number of energy audits performed, number of buildings retrofit), rather than "outcomes," which are the ultimate program results (e.g., energy and cost savings).

All together, there are nearly 80 enumeration indicators that describe state activities performed under the SEP. For nearly all of the 20 program areas, state activities are described by between two and four enumeration indicators each. For example, the enumeration indicators for the Workshops/Training program area are the number of workshops and training sessions developed, number of workshops and training sessions presented, and number of persons attending those sessions, all disaggregated by energy-consuming sector. For Retrofits, the indicators are the number of buildings retrofit, number of buildings receiving various types of measures, and building square footage, all reported by building type. Each set of enumeration indicators presents a complete picture of the important activities performed within its program area. 
Table 1. Program areas covered by enumeration indicators

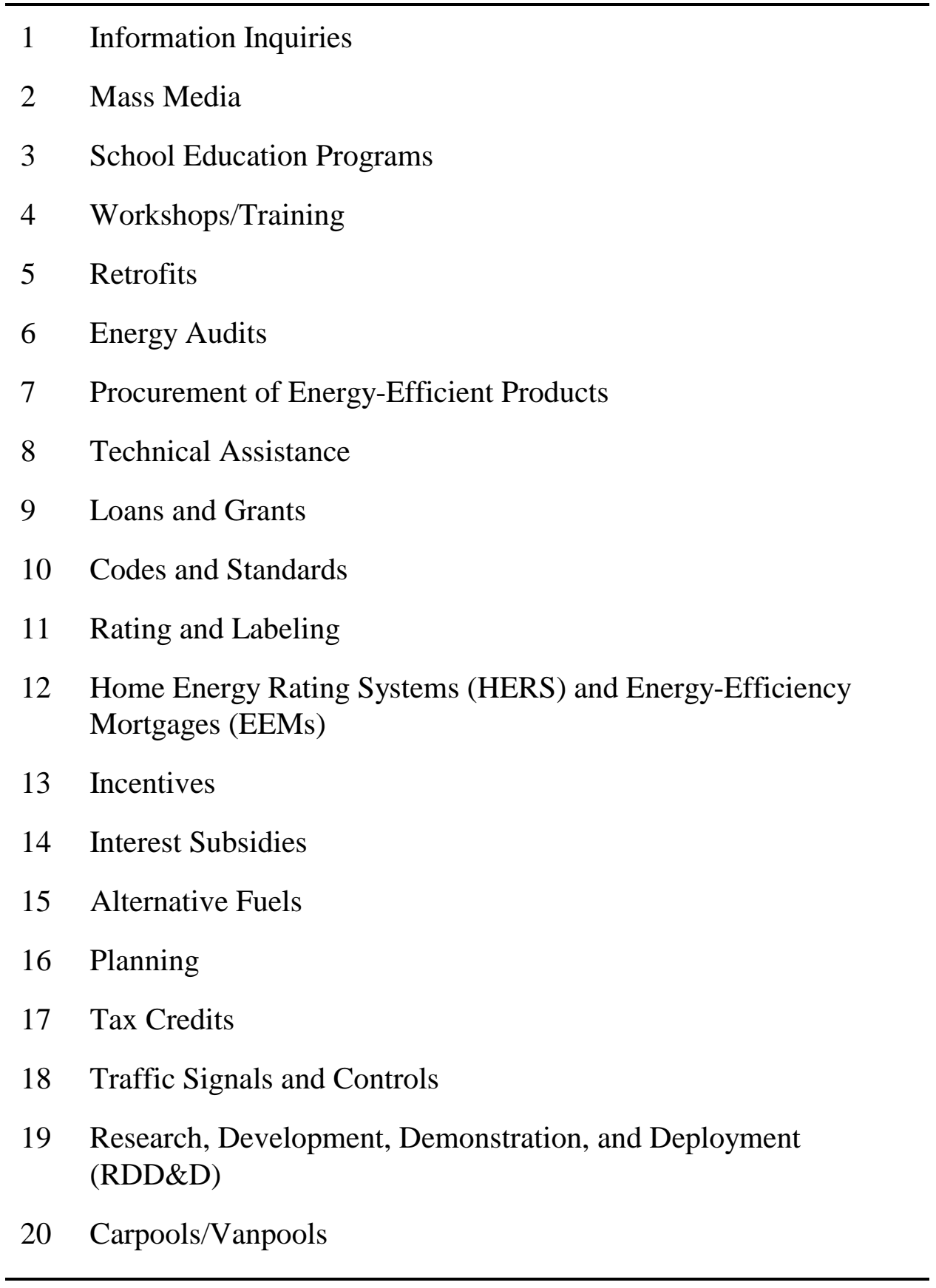


The enumeration indicators were developed to provide a uniform and systematic way for describing and measuring the broad range of SEP-supported activities undertaken by the various states and territories. This activity-based approach focuses on important program outputs and provides a detailed and comprehensive picture of what the SEP has accomplished in any given time period. It goes beyond a general description of the broad functional areas and energyconsuming sectors addressed to describe, in substantial detail, the specific actions that are taken by the states.

Although the enumeration indicators originally were developed to count program "outputs," they also can be used as a basis for estimating "outcomes." State-provided information on the number of activities undertaken can be multiplied by estimates of the amount of energy saved per activity, and the product will approximate energy savings for that program area. For example, if a state provides counts of the number of people attending workshops and training sessions and a coefficient is developed for average energy savings achieved per workshop participant, multiplying the first number by the second one will yield estimated energy savings within the Workshops/Training program area for that state. And that number can be multiplied by emissions reductions coefficients to yield estimates of the amount by which various types of emissions would be reduced.

While this study measures energy and cost savings and emissions reductions, it does not attempt to quantify other important benefits that also are associated with the SEP. These include positive effects on national security, the economy, and individual health and safety. Alternative Fuels programs, which receive a considerable portion of SEP funding, are designed to decrease petroleum consumption and increase the nation's energy security rather than to reduce the absolute amount of energy consumed. Energy emergency plans are developed to help communities address possible supply shortages and interruptions rather than to cut the total amount of energy use. And activities in other program areas also can have important economic, social, and national security effects in addition to the energy and costs savings and emissions reductions that they engender. These non-energy benefits are important, and intended, products of the SEP and contribute substantially to its social value. Accordingly, it must be acknowledged that the total benefits produced by SEP activities are greater than those quantified in this report.

\section{SCOPE OF REPORT}

Subsequent chapters of this report provide additional information on the methods used to quantify SEP activities and accomplishments and the major findings of that effort. Chapter 2 describes how enumeration indicators data were collected and how energy and cost savings and emissions reductions were calculated from them. In Chapter 3, we list the states that provided data for this study and the share of total SEP funding represented by each one. In addition, the number of states providing data in each of the 20 program areas is given, along with the amount of funding allocated to each area and the additional resources leveraged from non-SEP sources. Overall funding for all program areas combined is also described. Chapter 4 describes the energy 
and cost savings and emissions reductions achieved, overall and in the various individual program areas. Chapter 5 summarizes the key findings reported earlier and extrapolates savings and emissions reductions from the responding states to the SEP program nationwide. 


\section{METHODS}

\section{DATA COLLECTION}

ORNL prepared a set of electronic spreadsheets containing all enumeration indicators for each of the 20 program areas and presenting blank spaces in which representatives of the states could indicate the number of SEP-supported activities of each type in which they had engaged in their most recent completed program year. In early October of 2001, National Association of State Energy Officials (NASEO) staff contacted the appropriate people in the states, territories, and District of Columbia, and asked them to fill in the enumeration indicator spreadsheets, which were posted on the NASEO website (NASEO 2001), and return the completed materials to NASEO.

During the Fall of 2001, while state energy officials began to fill in the enumeration indicator spreadsheets with information about their SEP activities, ORNL staff developed estimates of per-unit energy savings for key activities in the various program areas ${ }^{1}$. The information for that endeavor came from recent evaluations focusing on the effects of various state energy efficiency and renewable energy programs. A number of articles published in journals and conference proceedings were reviewed, and findings were extracted from those that were relevant to this study and employed rigorous and well-accepted research methods. Using the best of the available data and drawing on their own previous research on SEP metrics, ORNL staff were able to develop per-unit energy-savings estimates for at least one enumeration indicator in each of 14 program areas. An effort was made to keep the energy-savings coefficients conservative by adjusting them downward to account for factors such as installation, savings-realization, and compliance rates, where appropriate. Energy-savings coefficients were not developed for six of the 20 program areas, either because insufficient data were available, the indicators did not lend themselves to the estimation of savings, or-in the case of Alternative Fuels - the program area's efforts were not primarily designed to save energy. In some program areas (e.g., HERS and EEMs), partial savings could be estimated but coefficients could not be developed for one or more important enumeration indicators or energy-consuming sectors.

In the 14 program areas where energy savings could be quantified, the individual savings estimates generally were taken from a limited number of studies and are applied broadly to the entire SEP. Accordingly, they must be recognized as approximations of actual savings. Despite this, the current study represents the most comprehensive and rigorous evaluation of the SEP performed to date, and the savings number presented in this document are valid estimates of program accomplishments. The program areas covered and the specific enumeration indicators

\footnotetext{
${ }^{1}$ Energy savings were expressed in terms of millions of British Thermal Units (BTUs), regardless of the fuel involved, to allow the combination of savings by different fuel types. Where the fuel in question was electricity, kilowatt hours were converted to source BTUs (i.e., the amount of energy required at the power plant to produce a specified amount of usable energy), using the formula: one $\mathrm{kWh}=0.010883$ million source BTUs. If electricity savings were expressed in site BTUs, they were converted to source BTUs by multiplying by 3.189. Source BTUs were used as the common unit of measurement to reflect the total amount of energy saved.
} 
for which savings coefficients were developed are shown in Table 2. A more complete discussion of the energy-savings coefficients used is provided in Appendix A.

Table 2. Enumeration indicators for which per-unit savings coefficients were developed

\begin{tabular}{|c|c|}
\hline Program area & Enumeration indicator \\
\hline - Workshops/Training & 1. Number of people attending workshops, by sector \\
\hline - Retrofits & 1. Number of buildings retrofit, by sector \\
\hline & 2. Floor space of buildings retrofit, by sector \\
\hline - Energy Audits & 1. Number of audits performed, by sector \\
\hline & 2. Floor space audited, by sector \\
\hline & 3. Projected energy savings, by sector \\
\hline $\begin{array}{l}\text { - Procurement of Energy- } \\
\text { Efficient Products }\end{array}$ & 1. Number of units purchased, by type \\
\hline - Technical Assistance & $\begin{array}{l}\text { 1. Number of recommendations made for energy-efficiency } \\
\text { measures or strategies, by sector }\end{array}$ \\
\hline - Loans and Grants & 1. Monetary value of loans given, by sector \\
\hline & 2. Monetary value of grants given, by sector \\
\hline - Codes and Standards & $\begin{array}{l}\text { 1. Number of energy-consuming systems or technologies for } \\
\text { which codes and standards are adopted at state or local } \\
\text { level, by sector }\end{array}$ \\
\hline - Rating and Labeling & $\begin{array}{l}\text { 1. Number of energy-consuming devices for which rating and } \\
\text { labeling systems are endorsed by the state }\end{array}$ \\
\hline - HERS and EEMs & $\begin{array}{l}\text { 1. Number of Energy Efficiency Mortgages issued in } \\
\text { conjunction with a Home Energy Rating System }\end{array}$ \\
\hline - Incentives & 1. Monetary value of rebates provided, by sector \\
\hline - Interest Subsidies & 1. Monetary value of interest subsidies provided, by sector \\
\hline - Tax Credits & 1. Monetary value of tax credits given, by sector \\
\hline - Traffic Signals and Controls & $\begin{array}{l}\text { 1. Number of energy-efficient traffic signals and controls } \\
\text { installed }\end{array}$ \\
\hline - Carpools/Vanpools & 1. Number of new carpools/vanpools formed \\
\hline
\end{tabular}




\section{CALCULATING SAVINGS AND EMISSIONS REDUCTIONS}

All state responses provided by August 31, 2002, were used in this analysis. For each relevant enumeration indicator, the number of activities reported by each responding state was multiplied by the associated per-unit savings coefficient. The energy-savings numbers calculated in this manner for each state were summed to get estimated total savings for all responding states, expressed as millions of source BTUs. Estimates of the cost savings to energy consumers were generated by multiplying the energy-savings estimates by $\$ 6.20$, which is the approximate average cost of one million source BTUs of energy for all energy-consuming sectors nationwide ${ }^{2}$. The key inputs used in the savings calculations and the resulting outcomes for each program area are presented in Appendix B.

Emissions reductions were calculated directly from the energy-savings estimates discussed above. Essentially, the amount of savings achieved by each state within each program area was multiplied by coefficients represented average emissions per million source BTUs for that program area for six different emissions types: Carbon; Nitrogen Oxide $\left(\mathrm{NO}_{\mathrm{x}}\right)$; Sulphur Dioxide $\left(\mathrm{SO}_{2}\right.$ ); Volatile Organic Compounds (VOCs); Carbon Monoxide (CO); and Fine Particulate Matter (PM10). For each program area, the emissions reductions of each type achieved by the various states were summed to get estimated total emissions reductions for all respondents. A more detailed description of the method discussed here is presented in Appendix C.

The savings and emissions reductions estimates for the responding states can be extrapolated to the nation as a whole based on the proportion of total SEP funding represented by the responding states ${ }^{3}$. For instance, if the responding states represent $50 \%$ of nationwide SEP funding, the estimates of combined savings or emissions reductions for those states can be multiplied by 2.0 (the inverse of 0.50 ) to give an approximation of what the numbers would be if all states had provided information on their SEP activities. Using this adjustment factor to extrapolate the findings to the entire United States yields imperfect results because it rests on the assumption that the non-responding states would achieve the same amount of energy savings per dollar of SEP funding as did the responding states. Despite the fact that the non-responding states are likely to differ somewhat from the responding states in the overall cost-effectiveness of their programs, the above-described method provides a defensible approximation of nationwide outcomes in all program areas combined. However, because the mix of SEP activities tends to vary substantially from state to state, we did not feel comfortable extrapolating results to the entire nation for each individual program area.

\footnotetext{
${ }^{2}$ Based on 2000 energy prices, the average cost of one million source BTUs of natural gas in all energyconsuming sectors was approximately $\$ 6.28$ and the average cost of one million source BTUs of electricity was $\$ 6.14$. Accordingly, $\$ 6.20$ per million source BTUs was used as an approximation of the cost of fuel of all types in all sectors.

${ }^{3}$ Data on each state's Fiscal Year 2000 SEP funding was taken from the WINSaga data base.
} 
Upon completing the data analysis, we prepared a draft report and sent it to a number of experts in the fields of energy efficiency and program evaluation for their review. We asked for comments on the entire document, with special attention to our detailed descriptions of the coefficients used to estimate energy savings. After receiving extensive reviewer comments, we adjusted the saving coefficients as necessary and thoroughly revised the entire document. A listing of the reviewers and their organizational affiliations is contained in the Acknowledgments section of this report. 


\section{DESCRIPTION OF RESPONDING STATES}

\section{KEY STATE CHARACTERISTICS}

Between late November 2001 and the end of August 2002, twenty states provided the requested enumeration indicator data for their most recent completed program year ${ }^{4}$. As shown in Figure 1, these states are spread across the entire United States, both from east to west and from north to south. They include the three most populous states in the nation (California, Texas, and New York) as well as the least populous state (Wyoming). Table 3 shows the percent of total U.S. population and the percent of total SEP funding represented by each of the responding states. Together, the 20 responding states represent $45.6 \%$ of all funds allocated by SEP in Fiscal Year 2000 (from formula grants and special project awards combined) and 49.6\% of the entire United States population. As a group, the respondents do a good job of representing the diversity of SEP activities and performance found nationwide.

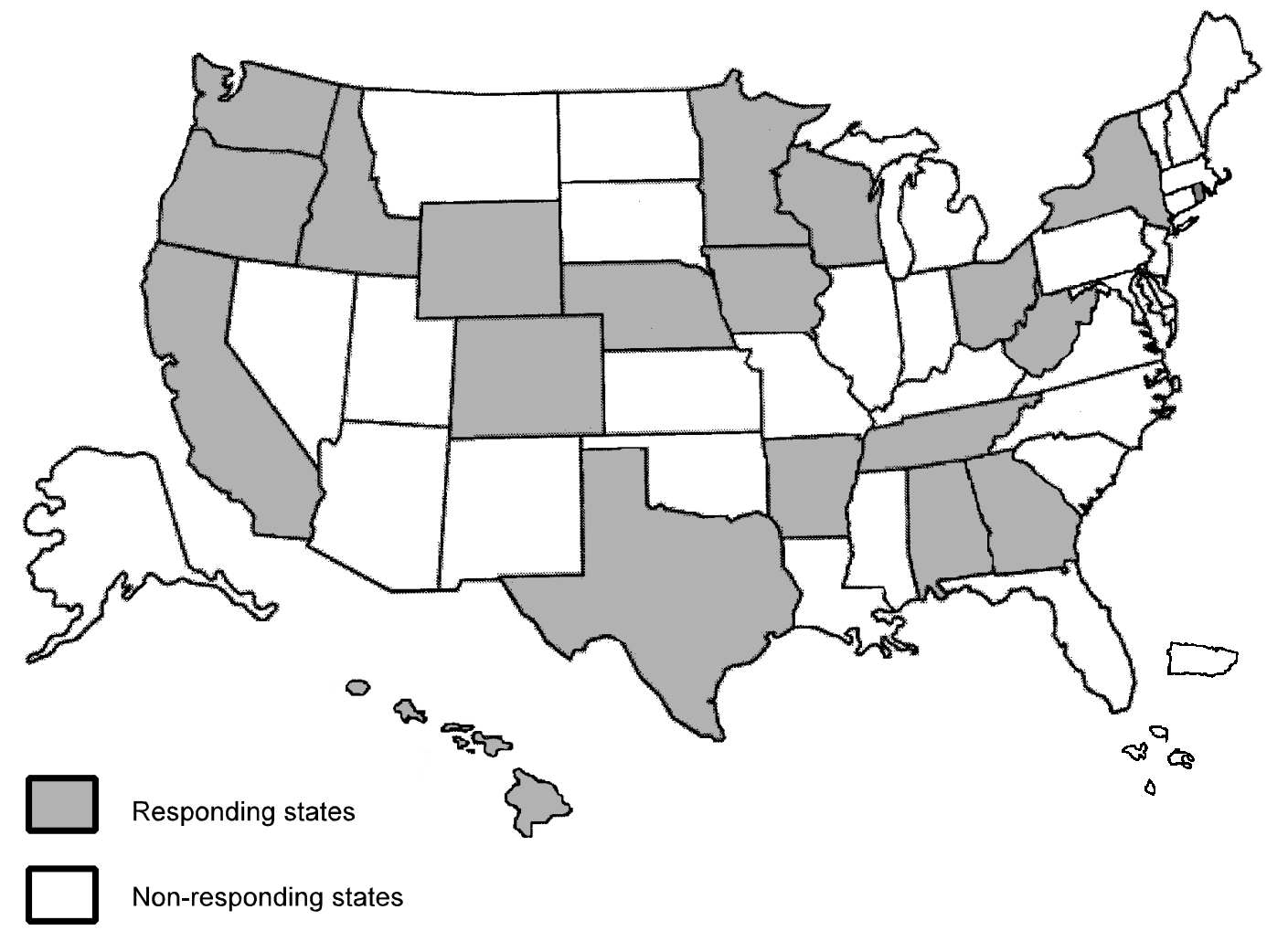

Figure 1. States providing enumeration indicators data.

\footnotetext{
${ }^{4}$ In addition to the states discussed in this document, one other state sent information on its funding but is not included in this study because it provided no data on its SEP activities.
} 
Table 3. Responding states: population and SEP funding as percent of total

\begin{tabular}{|c|c|c|}
\hline Responding state & $\begin{array}{l}\text { Percent of total U.S. } \\
\text { population }\end{array}$ & $\begin{array}{l}\text { Percent of total SEP } \\
\text { funding }\end{array}$ \\
\hline Alabama & 1.6 & 1.2 \\
\hline Arkansas & 0.9 & 0.9 \\
\hline California & 12.0 & 7.3 \\
\hline Colorado & 1.5 & 1.5 \\
\hline Georgia & 2.9 & 2.0 \\
\hline Hawaii & 0.4 & 0.8 \\
\hline Idaho & 0.5 & 1.4 \\
\hline Iowa & 1.0 & 2.3 \\
\hline Minnesota & 1.7 & 1.7 \\
\hline Nebraska & 0.6 & 1.0 \\
\hline New York & 6.7 & 5.7 \\
\hline Ohio & 4.0 & 3.4 \\
\hline Oregon & 1.2 & 1.5 \\
\hline Rhode Island & 0.4 & 0.9 \\
\hline Tennessee & 2.0 & 1.8 \\
\hline Texas & 7.4 & 5.1 \\
\hline West Virginia & 0.6 & 1.1 \\
\hline Washington & 2.1 & 2.7 \\
\hline Wisconsin & 1.9 & 2.7 \\
\hline Wyoming & 0.2 & 0.6 \\
\hline Total & 49.6 & 45.6 \\
\hline
\end{tabular}




\section{PROGRAM AREA ACTIVITY}

The number of states providing data for each program area is shown in Table 4. Clearly, there is substantially more state activity in some areas than in others. Three-fourths or more of the responding states conducted activities using SEP funds in the areas of Workshops/Training, Mass Media, Information

Table 4. Number of states providing data for each program area

\begin{tabular}{lc}
\hline Program area & Number of states providing data \\
\hline Workshops/Training & 19 \\
Mass Media & 18 \\
Information Inquiries & 17 \\
Loans and Grants & 16 \\
Technical Assistance & 16 \\
Alternative Fuels & 16 \\
Codes and Standards & 15 \\
RDD\&D & 13 \\
Planning & 12 \\
Retrofits & 12 \\
Energy Audits & 12 \\
School Education Programs & 10 \\
Procurement & 6 \\
HERS and EEMs & 2 \\
Incentives & 2 \\
Interest Subsidies & 2 \\
Carpools/Vanpools & 2 \\
Rating and Labeling & 2 \\
Tax Credits & 2 \\
Traffic Signals & 12 \\
\hline
\end{tabular}


Inquiries, Loans and Grants, Technical Assistance, Alternative Fuels, and Codes and Standards. And at least half of the states also reported engaging in SEP-supported activities related to RDD\&D, Planning, Retrofits, Energy Audits, and School Education. On the other end of the scale, less than one-fourth of the responding states were active in the areas of Traffic Signals and Controls, Tax Credits, Rating and Labeling, Carpools/Vanpools, and Interest Subsidies as part of their SEP efforts.

Table 5 shows the amount of funding allocated to each of the 20 program areas. The table shows the funding provided by the SEP program, the number of dollars leveraged from other sources for each SEP dollar received, and the total funding (SEP plus non-SEP). In addition, total funding in each program area as a percent of combined funding for all program areas - both for SEP funding alone and for all funding sources combined - is shown. The range of SEP funding extended from a high of over $\$ 4.7$ million (for Loans and Grants) to a low of zero for Low-Income Weatherization, Traffic Signals, and Tax Credits. The three most-heavily funded program areas (Loans and Grants, Codes and Standards, and Alternative Fuels) together accounted for over $58 \%$ of all SEP funding reported by the responding states. The top five (the previous three plus Information Inquiries and Technical Assistance) accounted for over $72 \%$ of SEP funding. And the top 10 program areas (the top five plus Energy Audits, Workshops/ Training, RDD\&D, Planning, and Mass Media) accounted for nearly 95\% of all SEP funds reported. Not surprisingly, those program areas receiving the largest share of SEP funding are also areas in which a majority of the responding states conducted activities.

For total funding (SEP plus non-SEP), Loans and Grants received the largest amount, followed by Alternative Fuels, HERS/EEMs, Technical Assistance, Codes and Standards, and Mass Media. The program areas with the lowest total funding were Tax Credits, Rating and Labeling, Carpools/Vanpools, Incentives, Procurement, Interest Subsidies, and Traffic Signals. This list of the most- and least-funded program areas is similar to the compilation presented above for SEP funding, with a few exceptions. HERS/EEMS, for example, did much better in terms of total funding than for SEP funds alone, while Codes and Standards did substantially worse. The reason for this is that some program areas leveraged substantially more funds from non-SEP sources than did others.

For all program areas, there appears to be substantial variation among the 20 responding states in the way they calculate the amount of money leveraged from other sources by SEP funding. Some states seem to report as leveraging only the amounts received from non-SEP sources that are spent on activities that are substantially supported by SEP funds and would not exist in the absence of that program. In contrast, other states report expenditures and activities in many areas where most of the funding comes from non-SEP sources, as long as those efforts are administered by the same office that manages the programs that are substantially supported by SEP funds. In several cases, states received large amounts of System Benefits Charge (SBC) money but that funding, and the substantial savings associated with the activities it supports, were not counted in this study. The observed differences in state reporting practices and the variety of funding sources utilized by State Energy Offices raise questions about how leveraging should be defined and what program activities, and funding amounts, should be counted as being 
Table 5. Reported allocation of funds, by program area

\begin{tabular}{|c|c|c|c|c|c|}
\hline Program area & $\begin{array}{c}\text { SEP } \\
\text { funding }(\$)\end{array}$ & $\begin{array}{l}\text { SEP funding } \\
\text { as percent of } \\
\text { total reported } \\
\text { for all } 20 \\
\text { program } \\
\text { areas }(\%)\end{array}$ & $\begin{array}{l}\text { Leveraged } \\
\text { dollars per } \\
\text { SEP dollar } \\
\quad(\$)\end{array}$ & $\begin{array}{c}\text { Total } \\
\text { funding: } \\
\text { SEP + } \\
\text { leveraged } \\
(\$)\end{array}$ & $\begin{array}{l}\text { Total funding as } \\
\text { percent of total } \\
\text { reported for all } \\
20 \text { program } \\
\text { areas }(\%)\end{array}$ \\
\hline Loans and Grants & $4,747,602$ & 22.11 & 3.77 & $22,669,225$ & 21.75 \\
\hline Codes and Standards & $4,056,277$ & 18.89 & 0.87 & $7,603,933$ & 7.29 \\
\hline Alternative Fuels & $3,732,475$ & 17.38 & 4.65 & $21,089,273$ & 20.23 \\
\hline Information Inquiries & $1,584,855$ & 7.38 & 1.09 & $3,313,461$ & 3.18 \\
\hline Technical Assistance & $1,375,131$ & 6.40 & 6.33 & $10,076,140$ & 9.66 \\
\hline Energy Audits & $1,153,789$ & 5.37 & 2.47 & $3,999,717$ & 3.84 \\
\hline Workshops/Training & $1,102,791$ & 5.14 & 2.60 & $3,974,310$ & 3.81 \\
\hline RDD\&D & $1,042,525$ & 4.86 & 3.77 & $4,970,596$ & 4.77 \\
\hline Planning & 885,692 & 4.13 & 0.43 & $1,269,502$ & 1.22 \\
\hline Mass Media & 650,413 & 3.03 & 10.14 & $7,245,308$ & 6.95 \\
\hline School Education & 373,373 & 1.74 & 3.37 & $1,633,493$ & 1.57 \\
\hline Retrofits & 280,823 & 1.31 & 5.21 & $1,743,700$ & 1.67 \\
\hline HERS/EEMs & 257,066 & 1.20 & 49.11 & $12,881,646$ & 12.36 \\
\hline Incentives & 115,922 & 0.54 & 1.78 & 322,701 & 0.31 \\
\hline Carpools/Vanpools & 76,992 & 0.36 & 2.16 & 242,996 & 0.23 \\
\hline Rating and Labeling & 13,311 & 0.06 & 0 & 13,311 & 0.01 \\
\hline Interest Subsidies & 10,787 & 0.05 & 32.17 & 357,849 & 0.34 \\
\hline Procurement & 10,787 & 0.05 & 31.19 & 347,240 & 0.33 \\
\hline Traffic Signals & 0 & 0 & N.A. & 506,000 & 0.49 \\
\hline Tax Credits & 0 & 0 & 0 & 0 & 0.0 \\
\hline $\begin{array}{l}\text { Total Reported by } \\
\text { Program Area }\end{array}$ & $21,470,611$ & 100.00 & 3.86 & $104,260,401$ & 100.00 \\
\hline
\end{tabular}


leveraged by SEP. We recognize the need for a uniform approach to defining and reporting leveraged funds for SEP and all other Energy Efficiency and Renewable Energy programs supported by DOE. Additional investigation of this topic seems to be warranted.

\section{OVERALL FUNDING}

Because several states reported the overall amount of SEP funding they received but did not specify the specific program areas to which it was allocated, actual SEP funding was higher than indicated in Table 5, which showed only those funds that were reported by program area. Table 6 shows that the 20 responding states reported receiving \$26,310,717 in SEP funds, of which approximately 61 percent was spent on programs for which energy savings could be quantified and 39 percent went to programs where the savings were not quantified.

Total funding for the responding states, including both SEP and non-SEP monies, amounted to $\$ 119,346,647$. Once again, this is greater than the amount reported in Table 5, which represents only those funds associated with a specific program area. Of the total amount, roughly 62 percent was spent on programs where the energy savings were quantified with the remaining 38 percent going to support programs with unquantified savings. For each dollar of SEP funding spent on all program types, the states received $\$ 3.54$ from other sources. The amount leveraged per SEP dollar was very similar for those programs where savings could be quantified and for programs without quantified savings.

Table 6. SEP funds, leveraged dollars, and total funding for responding states*

\begin{tabular}{lccc}
\hline & SEP funds & $\begin{array}{l}\text { Leveraged dollars } \\
\text { per SEP dollar (\$) }\end{array}$ & $\begin{array}{c}\text { Total funding: SEP } \\
\text { + leveraged (\$) }\end{array}$ \\
\hline $\begin{array}{l}\text { Programs for which savings } \\
\text { are quantified }\end{array}$ & $16,177,233$ & 3.58 & $74,106,322$ \\
$\begin{array}{l}\text { Programs for which savings } \\
\text { are not quantified }\end{array}$ & $10,133,484$ & 3.46 & $45,240,325$ \\
\hline $\begin{array}{l}\text { Total } \\
\text { *Includes state totals not reported by program area. The allocation of funds among quantified and non-quantified programs is } \\
\text { an approximation, based on the mix of program expenditures reported by those states that disaggregated funding by program } \\
\text { area. }\end{array}$ &
\end{tabular}




\section{PROGRAM SAVINGS AND EMISSIONS REDUCTIONS}

\section{SAVINGS AND EMISSIONS REDUCTIONS BY PROGRAM AREA}

The estimated energy and cost savings achieved by each of the 14 program areas for which savings could be calculated are presented in Table 7. Codes and Standards activities accounted for approximately one-third of the total energy savings. The magnitude of these savings is partly due to the fact that there was intensive code activity in the high population states of California, Texas, and New York, where a very large number of buildings would be affected by the energy-efficient codes and standards enacted. In general, Codes and Standards activities can be expected to save energy cost-effectively, especially in areas with substantial building activity, because the adoption of codes and standards is relatively inexpensive while the results, which typically apply to entire states, are wide-reaching.

The estimated amount of energy saved by Energy Audits also was large (nearly 18\% of total energy savings). According to the responding states, most of those savings occurred in the institutional sector (i.e., government buildings, schools, and hospitals). The Energy Audits savings number is based largely on state projections of how much energy would be saved as a result of the audits that were performed ${ }^{5}$. It makes sense that audits would achieve relatively high savings per dollar spent because, in most cases, the program pays only for the audit itself and not for the actual energy efficiency improvements made as a result of the audit recommendations.

Substantial savings also were achieved in the areas of Rating and Labeling, Workshops and Training, and Incentives. In each of these program areas, the amount of energy saved relative to the magnitude of funding is high because the program does not pay the full cost of the energy-saving actions that ultimately are taken. These three program areas, in conjunction with Codes and Standards and Energy Audits, account for approximately 85 percent of the savings achieved in all areas combined. When the next three highest-saving program areas-Retrofits, Loans and Grants, and Technical Assistance—are added, cumulative savings amount to 98 percent of the total.

The lowest amount of energy savings occurred in the areas of Traffic Signals, Tax Credits, Procurement, Carpools/Vanpools, Interest Subsidies, and HERS/EEMs. In all cases, activities in these program areas were undertaken by less (often much less) than one-third of the

\footnotetext{
${ }^{5}$ Coefficients were developed to calculate energy savings from the number of audits performed and from the square footage of the area audited. However, where the states provided their own estimates of audit-related energy savings, those numbers were used, after adjusting them downward to reflect the expectation that only half of the recommended measures would be installed and that only a portion of projected savings (60\% in the residential sector and about $90 \%$ elsewhere) would actually be realized by the measures taken. Based on those expectations, we multiplied state-projected savings by adjustment factors of 0.3 in the residential sector and 0.45 in all other sectors.
} 
responding states, and the amount of SEP funding allocated to them was relatively small.

Table 7. Estimated annual energy and cost savings, by program area

\begin{tabular}{|c|c|c|c|}
\hline Program area & $\begin{array}{c}\text { Estimated } \\
\text { annual energy } \\
\text { savings (million } \\
\text { source BTUs) }\end{array}$ & $\begin{array}{c}\text { Estimated annual } \\
\text { cost savings }(\$)\end{array}$ & $\begin{array}{l}\text { Estimated energy } \\
\text { savings as percent of } \\
\text { total savings in all } \\
\text { program areas }(\%)\end{array}$ \\
\hline Codes and Standards & $6,396,625$ & $39,659,074$ & 33.91 \\
\hline Energy Audits & $3,354,427$ & $20,797,448$ & 17.79 \\
\hline Rating and Labeling & $2,466,907$ & $15,294,823$ & 13.08 \\
\hline Workshops/Training & $2,069,284$ & $12,829,559$ & 10.97 \\
\hline Incentives & $1,815,481$ & $11,255,984$ & 9.63 \\
\hline Retrofits & 970,465 & $6,016,901$ & 5.15 \\
\hline Loans and Grants & 860,693 & $5,336,295$ & 4.56 \\
\hline Technical Assistance & 580,422 & $3,598,618$ & 3.08 \\
\hline Traffic Signals & 196,053 & $1,215,529$ & 1.04 \\
\hline Tax Credits & 78,507 & 486,744 & 0.42 \\
\hline Procurement & 49,867 & 309,173 & 0.26 \\
\hline Carpools/Vanpools & 19,143 & 118,686 & 0.10 \\
\hline Interest Subsidies & 1,291 & 8,007 & 0.01 \\
\hline HERS and EEMs & 301 & 1,865 & 0.002 \\
\hline Total & $18,859,466$ & $116,928,706$ & 100.00 \\
\hline
\end{tabular}

Emissions reductions are based directly on the energy savings described above. Accordingly, the rank order of the program areas, and the relative magnitude of the outcomes achieved in each one, are the same for emissions reductions (Table 8) as for energy savings (Table 7). 


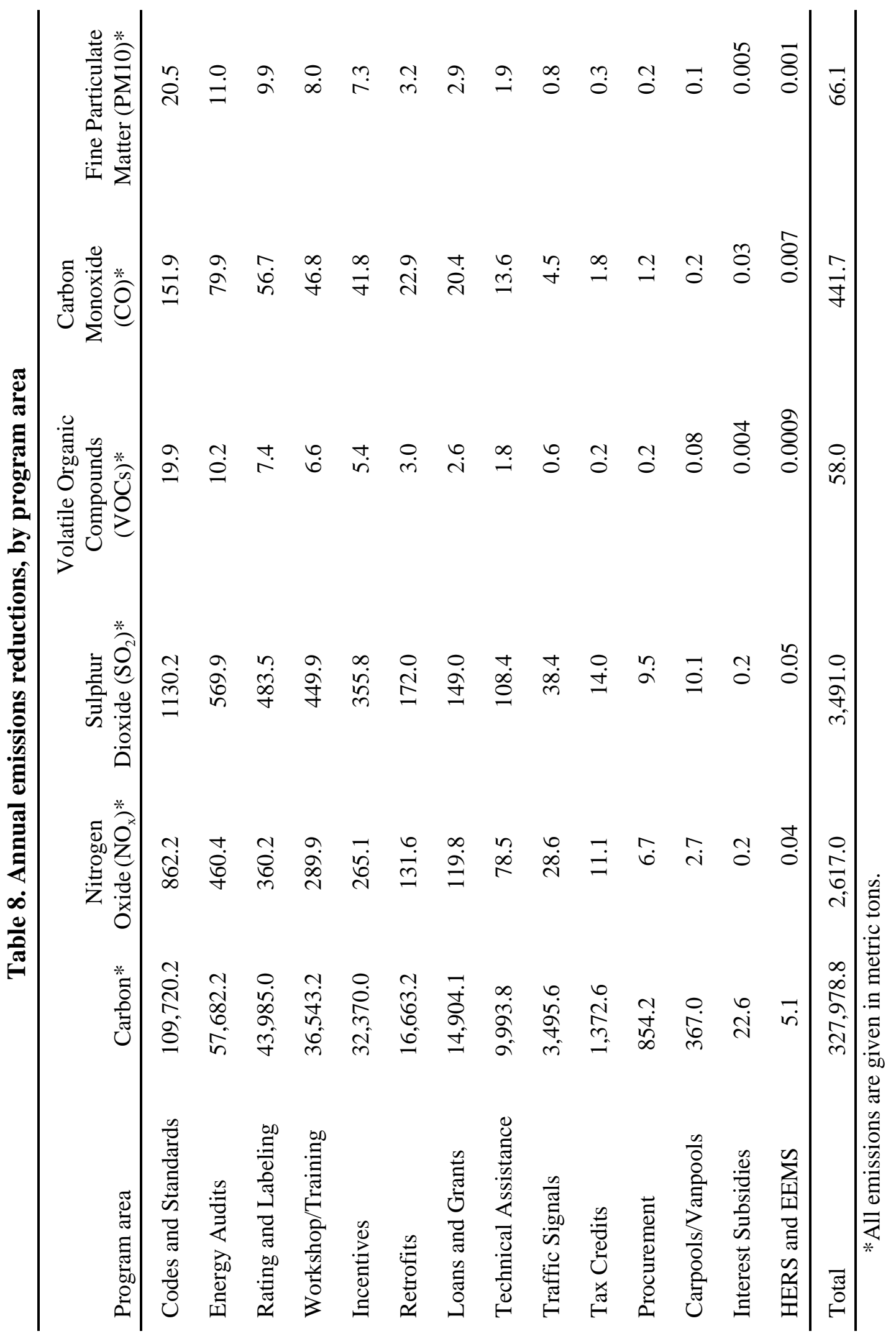




\section{TOTAL SAVINGS AND EMISSIONS REDUCTIONS}

As shown at the bottom of Table 7, annual energy savings totaled nearly 19,000,000 million source BTUs for all 14 program areas for which outcomes could be quantified. For those same program areas, estimated annual cost savings amounted to almost $\$ 117$ million. It is important to note that actual energy and cost savings are likely to be higher than those reported here, because savings were not calculated for six of the 20 program areas. Also, the annual savings described here are likely to continue over time, because the effects of the SEP-supported energy-saving measures tend to last for many years.

In the responding states, each dollar of SEP funding spent on programs where savings could be quantified resulted in estimated annual energy savings of 1.17 million source BTUs and estimated annual cost savings of $\$ 7.23$ (Table 9). Each dollar of total reported funding (SEP plus leveraged non-SEP) in those same program areas resulted in annual energy savings of 0.25 million source BTUs and annual cost savings of $\$ 1.58$. This means that the payback period was 0.14 years for the SEP portion and 0.63 years for the total investment. ${ }^{6}$

Table 9. Estimated annual savings achieved in responding states per dollar of funding for program areas where savings are quantified*

\begin{tabular}{lcc}
\hline & $\begin{array}{c}\text { Estimated annual energy } \\
\text { savings (million source } \\
\text { BTUs) }\end{array}$ & $\begin{array}{c}\text { Estimated annual cost } \\
\text { savings (\$) }\end{array}$ \\
\hline Per dollar of SEP funding & 1.17 & 7.23 \\
Per dollar of total funding & 0.25 & 1.58 \\
\hline
\end{tabular}

*Savings and funding numbers are only from those 14 program areas where savings could be quantified.

As shown at the bottom of Table 8 , it is estimated that carbon emissions were reduced by nearly 328,000 metric tons annually in those 14 program areas where energy savings could be quantified. The magnitude of emissions reductions was much smaller, but still considerable, for the other substances studied. Both $\mathrm{SO}_{2}$ and $\mathrm{NO}_{\mathrm{x}}$ emissions were reduced by over 2,500 metric tons per year, and annual $\mathrm{CO}$ reductions totaled nearly 450 metric tons.

It is important to note that the SEP also generates substantial benefits in other areas—-such as national security, the economy, health and safety—that are not quantified in this report.

${ }^{6}$ Payback periods represent the length of time that it takes for program-generated cost savings to equal the amount of money provided by particular sources: DOE's SEP contribution in the first instance and SEP monies plus all reported leveraged contributions in the second. In some cases, unreported investments are made by these entities receiving the services in question (e.g., expenditures made by those implementing energy-efficiency improvements suggested during workshops and training sessions), and they are not factored into the payback calculations. 


\section{SUMMARY AND CONCLUSIONS}

\section{SUMMARY OF FINDINGS FROM RESPONDING STATES}

A large majority of the responding states were active in the areas of Workshops/Training, Mass Media, Information Inquiries, Loans and Grants, Technical Assistance, Alternative Fuels, and Codes and Standards. These program areas are largely the same as those that received the greatest amount of SEP funding, and both sets of programs have substantial overlap with those areas for which total funding (SEP plus leveraged non-SEP) was greatest.

The 20 responding states received just over \$26 million in SEP funds. Total reported funding, including both SEP and non-SEP monies, amounted to over $\$ 119$ million. The states obtained \$3.54 from non-SEP sources for each dollar of SEP funding, but it should be noted that some approaches to defining leveraged funds would result in higher numbers being reported here.

Of the total energy savings, approximately 85 percent occurred in the top five program areas: Codes and Standards, Energy Audits, Rating and Labeling, Workshops and Training, and Incentives. The next three highest-saving program areas-Retrofits, Loans and Grants, and Technical Assistance - accounted for nearly all of the remaining energy savings.

Annual energy and cost savings were estimated to total nearly 19,000,000 million source BTUs and almost $\$ 177$ million, respectively, for all 14 program areas for which outcomes could be quantified. These numbers almost certainly underestimate actual savings because per-unit savings coefficients could not be developed for one or more important enumeration indicators or energy-consuming sectors in some of these 14 areas, and no energy-savings numbers could be generated for the other 6 program areas. Each dollar of SEP funds allocated to the 14 areas where savings were quantified resulted in annual savings of 1.17 million source BTUs and \$7.23 by responding states. For total (SEP plus non-SEP) funding, estimated annual savings were 0.25 million source BTUs and $\$ 1.58$ per dollar spent on those same program areas. The funds provided by SEP were paid back by program-generated savings in 0.14 years, and the total reported investment was repaid in 0.63 years. And because the effects of the states' energysaving activities tend to last for many years, the benefits continue to add up over time.

Total estimated emissions reductions were very large in those program areas where energy savings could be quantified. Carbon reductions, at nearly 328,000 metric tons per year, were much greater than for all the other emissions categories combined. However, substantial reductions also were achieved for other emissions, most notably $\mathrm{SO}_{2}, \mathrm{NO}_{\mathrm{x}}$, and $\mathrm{CO}$.

It is important to note that the estimates of cost savings presented in this document do not include the monetized value of emissions reductions nor of any other non-energy benefits (e.g., social, economic, national security) associated with program activities. If the full monetary value of those benefits were quantified, total savings attributed to the SEP would probably be considerably greater than indicated here. 


\section{EXTRAPOLATION OF FINDINGS TO STATE ENERGY PROGRAM NATIONWIDE}

As explained in Chapter 2, estimated savings for the responding states can be extrapolated to the nation as a whole. Since the 20 responding states combined receive $45.6 \%$ of total SEP funding, a rough estimate of nationwide savings can be produced by multiplying energy and cost savings for this group by an adjustment factor of 2.19298 (the inverse of 0.456). Because this extrapolation is based on the assumption that the ratio of savings per SEP dollar would be the same for non-respondents as for the 20 responding states, the resulting numbers must be treated with some caution. Table 10 shows that, based on the savings estimates generated for the responding states and the adjustment procedure described above, estimated annual energy and cost savings for the nation as a whole would be 41,358,478 million source BTUs and $\$ 256,422,600$, respectively. The estimated annual energy and cost savings per dollar of funding would be the same for the entire nation as reported for the responding states in Table 9 , based on the assumption that program expenditures would yield the same results in nonresponding states as in the responding ones.

Table 10. Total annual energy and cost savings for responding states and entire nation

\begin{tabular}{lcc}
\hline & Total for responding states & Extrapolated total for nation* \\
\hline $\begin{array}{l}\text { Estimated annual energy } \\
\text { savings (million source }\end{array}$ & $18,859,466$ & $41,358,478$ \\
$\begin{array}{l}\text { BTUs) } \\
\text { Estimated annual cost } \\
\text { savings (\$) }\end{array}$ & & \\
\hline
\end{tabular}

*Extrapolated to entire U.S. using adjustment factor of 2.19298 (the inverse of 0.456 , which is the proportion of total

SEP funding received by responding states).

Table 11 shows extrapolated emissions reductions for the entire nation based on information provided by the 20 responding states. Using the extrapolation method described above, carbon emissions would be reduced by nearly 720,000 metric tons; $\mathrm{SO}_{2}$ and $\mathrm{NO}_{x}$ emissions each would shrink by over 5,500 metric tons; and $\mathrm{CO}$ emissions would be reduced by nearly 1,000 metric tons. VOCs and PM10 reductions would be less, but still substantial.

\section{CONCLUSIONS}

As pointed out in the Methods discussion, the individual savings estimates that formed the basis of our savings calculations generally were taken from a limited number of studies and, accordingly, must be treated as approximations when applied to SEP as a whole. In order to improve current savings estimates, and generate new ones where none currently exist, additional evaluations of various SEP activities that quantify the resulting savings are needed. 
Table 11. Total annual emissions reductions for responding states and entire nation

\begin{tabular}{lrc}
\hline Emissions type & $\begin{array}{c}\text { Total reduction for responding } \\
\text { states (metric tons) }\end{array}$ & $\begin{array}{c}\text { Extrapolated total for } \\
\text { nation (metric tons) }\end{array}$ \\
\hline Carbon & $327,978.8$ & $719,251.8$ \\
$\mathrm{NO}_{x}$ & $2,617.0$ & $5,739.0$ \\
$\mathrm{SO}_{2}$ & $3,491.0$ & $7,655.7$ \\
$\mathrm{VOCs}$ & 58.0 & 127.2 \\
$\mathrm{CO}$ & 441.7 & 968.7 \\
$\mathrm{PM} 10$ & 66.1 & 144.8 \\
\hline
\end{tabular}

As discussed previously, the responding states displayed substantial variation in how they calculated the amount of support leveraged from non-SEP sources. These differences among states suggest the need for a uniform approach to defining and reporting leveraged funds and activities, not just for SEP but also for DOE's other Energy Efficiency and Renewable Energy programs. Future research in this area is likely to provide substantial benefits by making the reporting of results more consistent, both within and among the various DOE programs.

Despite the methodological limitations noted above, and the concomitant need for additional research, the estimates of energy and cost savings and emissions reductions presented in this report provide useful and valid information on what the State Energy Program has accomplished in its most recent year of operation. It is true, as noted previously, that there is some uncertainty associated with the savings estimates for the 20 responding states and that additional uncertainty is added when those findings are extrapolated to the nation as a whole. However, it is important to remember that the estimates given here are based on detailed descriptions of SEP activities provided by the largest states in the nation and a number of smaller ones, representing every major geographic region of the United States. The large savings and emissions reductions numbers, the substantial ratios of savings to funding, and the very short payback periods, while not precise, indicate that the SEP is operating effectively and is having a substantial positive impact on the nation's energy situation and its natural environment. 



\section{ACKNOWLEDGMENTS}

We would like to thank the following people for their important contributions. Joel Eisenberg, our colleague at Oak Ridge National Laboratory (ORNL), provided valuable guidance and support throughout this project and all the State Energy Program metrics work that proceeded it. The National Association of State Energy Officials (NASEO) provided helpful comments and advice to Oak Ridge National Laboratory staff during the development of the enumeration indicators, worked with the states to help them respond to the request for indicators data, and also reviewed the first draft of this document. Terry Sharp, Mark Ternes, and Mike MacDonald, all of ORNL, provided technical advice that was very helpful in refining the energysavings coefficients used in this study. Valuable reviews of the draft document were provided by a number of people, including: Michaela Martin of ORNL; Roya Stanley of the National Renewable Energy Laboratory (NREL); Faith Lambert and Dan Beckley of the U.S. Department of Energy (DOE); Frank Bishop, David Terry, Jeff Genzer, and John Nunley of NASEO; Nick Hall of TecMRKT Works; and Dave Barker of the Oregon Energy Office. Finally, Karen Bowman and Tracy Bodine at ORNL assembled the report and provided substantial support throughout the process. 



\section{REFERENCES}

Abraham, M., and J. MacDonald, 1995. Energy Conservation Opportunities in Small Commercial Buildings, ORNL/CON-414, Oak Ridge National Laboratory, Oak Ridge, Tennessee, August.

Applied Technology Research Corporation, 1995. Economic and Fiscal Impacts of the Energy Rated Homes of Louisiana Program, Prepared for Louisiana Department of Natural Research, March. www.leeric.lsu.edu/energy/impacts/intro.html

Building Systems Engineering and Building Systems Management, 2001. "Energy Presentation to the SAB, 5/23/01." http://www.bsmesi.com/sab.html

Clinton, J., H. Geller, and E. Hirst, 1986. "Review of Government and Utility Energy Conservation Programs," Annual Review of Energy 1986, 95-142.

Coates, B., 1995. "Persistence of Energy Savings in Commercial Buildings," 1995 Energy Program Evaluation Conference, 649-655, Chicago, IL.

Cohen, S.D., C. A. Goldman, and J. P. Harris, 1991. Measured Energy Savings and Economics of Retrofitting Existing Single-Family Homes: Am Update of the BECA-B Database . LBL-28147, Vol. II, February.

Commercial Building Energy Consumption Survey (CBECS), 1995.

Consortium for Energy Efficiency, 2001. Energy-Efficient Traffic Signals: Fact Sheet, http://www.ceeformt.org/resrc/facts/led-fx.php3

ENERGY STAR website, 2000, http://www.energystar.gov

Feldman, S. and B. Tannenbaum, 2000. "Swoosh!? Awareness and Effects of the ENERGY STAR Brand in Wisconsin Appliance Efficiency Programs," ACEEE Summer Study 2000, 6.107-119, American Council for an Energy-Efficient Economy, Washington, DC.

Gas Appliance Manufacturers Association, 1999. Statistical Highlights: Ten Year Summary, 1989-1998. Arlington, VA: GAMA.

Greely, K., J. Harris, and A. Hatcher, 1990. "Measured Energy Savings and Cost-Effectiveness of Conservation Retrofits in Commercial Buildings," ACEEE 1990 Summer Study on Energy Efficiency in Buildings, American Council for an Energy-Efficient Economy, Washington, DC. 
Greene, D. L., 1986. Driver Energy Conservation Awareness Training: Review and Recommendations for a National Program, ORNL/TM-9897, Oak Ridge National Laboratory, Oak Ridge, TN, May.

Haberl., J. et al., 2000. "Rebuild America Program in Texas: Update on the Brazos Valley Energy Conservation," ACEEE Summer Study 2000, 4.117-130, American Council for an Energy-Efficient Economy, Washington, DC.

Jones, T., D. Norland, and B. Prindle, 1998. Opportunity Lost. Better Energy Codes for Affordable Housing and a Cleaner Environment. Alliance to Save Energy, Washington, DC.

Lew, V., and J. Wang, 1998. "Do Completed Projects Result in Energy savings? ACEEE Summer Study 1998, 4.237-248, American Council for an Energy-Efficient Economy, Washington, DC.

Louisiana Department of Natural Resources, 2001. Institutional Conservation Program, http://www.dnr.state.la.us/SEC/EXECDIV/TECHASMT/programs/institutional/icp.htm

McLain, H., S. Leigh, and J. McDonald, 1994. Analysis of Savings Due to Multiple Energy Retrofits in a Large Office Building, ORNL/CON-363, Oak Ridge National Laboratory, Oak Ridge, Tennessee, May.

Nadel, S., and D. Goldstein, 1996. "Appliance and Equipment Efficiency Standards: History, Impacts, Current Status, and Future Directions," ACEEE Summer Study, 1996, 9:159-165, American Council for an Energy-Efficient Economy, Washington, DC.

Nadel, S., L. Rainer, M. Shepard, M. Suozzo, and J. Thorne, 1998. Emerging Energy-Saving Technologies and Practices for the Building Sector, American Council for an EnergyEfficient Economy, Washington, DC.

National Association of State Energy Officials, 2001. SEP Metrics, http://www.naseo.org/projects/sep/default.htm.

New York State Energy Research and Development Authority, 2001. Quarterly Report, June 2001, pp. 1-16.

Oregon Office of Energy, 2000. Tax Credits and Loans for Energy-Saving Projects, http://www.energy.state.or.us/bus/tax/pgt.htm

Pacific Gas and Electric Company, 2001. Equipment Rebates: Express Efficiency Program, www.pge.com/003_save_energy/003b_bus/003b1a_equip_rebate.shtml 
Residential Energy Services Network, 2001. Home Energy Ratings: A Primer. http://www.natresnet.org/herseems/HERSPrimer/HP04.htm

Rutgers University, 1999. Industrial Assessment Center Program, Fiscal Year 1999 Annual Report, http://oipea-www.rutgers.edu/

Schweitzer, M. and J. Eisenberg, 2002. Meeting the Challenge: The Prospect of Achieving 30 Percent Savings Through the Weatherization Assistance Program, ORNL/CON-479, Oak Ridge National Laboratory, Oak Ridge, TN, May.

Schweitzer, M., L. G. Berry, D. W. Jones, and B. E. Tonn, 2002. "Quantifying the Outputs of the State Energy Program: The Enumeration Indicators Approach," Energy Studies Review, Vol. 10, No. 2, 140-156.

U.S. Department of Energy, 2001a. State Energy Program, http://www.eren.doe.gov/buildings/state energy

U.S. Department of Energy, 2001b. GPRA Data Call 2003. Office of Energy Efficiency and Renewable Energy, Washington, DC, September 14.

U.S. Department of Energy, 2002a. 1999 Commercial Buildings Energy Consumption Survey. Energy Information Administration, Washington, DC.

U.S. Department of Energy, 2002b. FEMP's Energy Cost Calculators. http://www.eren.doe.gov/femp/procurement/calc-index.html

U.S. Department of Energy, 2002c. Performance Planning Guidance FY 04-08, Draft, Office of Energy Efficiency and Renewable Energy, Washington, DC, May 7.

U.S. Environmental Protection Agency, 2002a. Assessments and Modeling. http://www.epa.gov/otaq/transp/traqmodl.htm

U.S. Environmental Protection Agency, 2002b. Simple Savings Calculator. http://www.epa.gov/nrgystar/purchasing/2c_savings_calc.html

Webber, C.A., R.E. Brown, and J.G. Koomey, 2000. "Savings Estimates for the ENERGY STAR Voluntary Labeling Program,” Energy Policy 28, 1137-1149.

Wenzel, T. P., I.G. Koomey, G. J. Rosenquist, M. Sanchez, and J. W. Hanford, 1997. Energy Data Sourcebook for the U.S. Residential Sector, LBL-4027/UC-1600, Lawrence Berkeley National Laboratory, September. 



\section{APPENDIX A. DEVELOPMENT OF ENERGY-SAVINGS COEFFICIENTS}

ORNL staff developed per-unit savings estimates for at least one enumerator indicator in each of 14 program areas. Each of these estimates describes the primary energy savings (expressed in million source BTUs) associated with a specific activity (e.g., the performance of a single energy audit).We also generated an estimate of petroleum savings for selected activities in the Alternative Fuels area. Each of these per-unit savings estimates (or coefficients) can be multiplied by the number of activities reported by the states in the relevant program area to calculate total savings.

In a few program areas, we developed coefficients for more than one enumeration indicator. In the case of Loans and Grants, the different per-unit savings estimates apply to mutually exclusive activities, so the savings calculated by using both of them can be summed to get total savings for the entire program area. However, in the other two cases where multiple coefficients were developed (Retrofits and Energy Audits), only one of these multipliers was used for each state, to avoid double-counting savings related to the reported activities. In the Retrofits area, coefficients were developed for use both with number of buildings and number of square feet retrofitted. If a state provided square footage data, that was used to calculate savings because it was expected to yield a more accurate estimate; otherwise, savings were calculated from the number of buildings retrofit. For Audits, state-provided estimates of savings (in an adjusted form described later in this Appendix) were used if available. Otherwise, square footage served as the basis for our savings calculation. If data were provided for neither of those indicators, we calculated savings from the number of buildings retrofit.

For each enumeration indicator, we typically developed different savings coefficients for the various end-use sectors. A discussion of how each coefficient was developed-organized by program area, enumeration indicator, and end-use sector-is provided below.

\section{WORKSHOPS AND TRAINING}

\section{Indicator: Number of people attending workshops, by sector}

Energy savings resulting from training workshops were estimated separately for training involving commercial buildings and transportation.

\section{Commercial Buildings}

From the 1995 Commercial Building Energy Consumption Survey (CBECS) (U.S. DOE 1998), we (1) identified the amount of primary energy used by all commercial sector buildings; (2) calculated the amount of primary energy used per building; and (3) determined the average amount of primary energy used for HVAC and lighting, respectively. These calculations showed that the average commercial building used 753.7 million source BTUs for HVAC purposes and 
793.0 million source BTUs for lighting. The 1995 CBECS data were used for this because the 1999 CBECs (U.S. DOE 2002a) does not provide complete end use data at the time of this writing.

From McLain et al. (1994) and Abraham and MacDonald (1995), we obtained estimates of percent energy savings possible from HVAC and lighting retrofits in large and small office buildings. Because the buildings examined in those documents were selected for their unusually high savings opportunities, the reported savings were divided in half to better represent the potential savings achievable in more typical office buildings. Those savings numbers were then multiplied by an installation rate of 0.50 , to reflect the conservative assumption that only half the energy-efficiency measures presented in workshops and training sessions would actually be installed by the attendees. For the small commercial buildings described in Abraham and MacDonald, potential savings were also multiplied by a realization rate of 0.9 because the numbers presented in the report came from projections rather than actual measurement. The adjusted numbers thus calculated for large and small buildings were averaged to yield estimated savings of 13.1 percent of HVAC measures and $8.0 \%$ for lighting measures.

The average commercial building consumption of 753.7 million source BTUs for HVAC purposes was multiplied by the 13.1 percent savings number to give us average annual savings of 98.7 million source BTUs per building. For lighting, the average consumption of 793 million source BTUs was multiplied by savings of 8.0 percent to yield average annual savings of 63.4 million source BTUs per building.

From Reid et al. (1999), we obtained estimates of the number of buildings affected per trainee in a training session. We multiplied the energy savings per building by the mean number of buildings (four) to obtain the energy savings per trainee for lighting training, HVAC training, and a simple average of the two.

Table A.1 reports the estimated savings per building and per trainee for each type of training and also gives average savings for the two. Reid et al.'s data on the number of buildings influenced per trainee were influenced by an outlier. Thirty-eight percent of participants in their study influenced two to five buildings, and 20 percent influenced six to ten. Beyond the six-toten range, the percentages of participants dwindled sharply, but 23 percent of participants reported influencing 21 buildings or more. Without excluding the outlier, the weighted average number of buildings influenced was nine, and the weighted median was four. We used the weighted median number of buildings influenced and mean savings for the two types of training to get a value of 324.4 million source BTUs per workshop attendee. 
Table A.1. Energy savings in commercial buildings training

\begin{tabular}{cccc}
\hline & $\begin{array}{c}\text { Type of } \\
\text { training }\end{array}$ & $\begin{array}{c}\text { Million source } \\
\text { BTUs/bldg }\end{array}$ & $\begin{array}{c}\text { Million source BTUs/trainee, } \\
\text { four buildings influenced }\end{array}$ \\
\hline $\begin{array}{c}\text { All } \\
\text { commercial } \\
\text { buildings }\end{array}$ & HVAC & 98.7 & $\mathbf{3 9 4 . 8}$ \\
\hline & lighting & 63.4 & $\mathbf{2 5 3 . 6}$ \\
\hline & mean & 81.1 & $\mathbf{3 2 4 . 4}$ \\
\hline
\end{tabular}

\section{Vehicles}

We considered two types of training workshop directed at vehicles: maintenance and energy-efficient driving. For both types of vehicle training, we used a combined engineering savings/behavioral discount parameter of 0.106, from Greene (1986). In other words, both the improved maintenance derived from the maintenance training and the better driving from the driver training were expected to improve fuel mileage by 10.6 percent. The savings parameter of 0.106 was multiplied by annual per-vehicle fuel consumption, which was calculated by dividing the assumed distance driven each year by a single government vehicle (12,000 miles) by the miles per gallon (19.0) associated with an unweighted average of common vehicle types.

The vehicle types and their mileages are:

- compact autos: $23.5 \mathrm{mpg}$ city

- mid-size autos: $19.6 \mathrm{mpg}$, city

- trucks (average): $17 \mathrm{mpg}$, city

- vans (average): $16 \mathrm{mpg}$, city

- unweighted average: $19.0 \mathrm{mpg}$

The calculation $(0.106) \times(12,000$ miles/year $) / 19.0 \mathrm{mpg}$ yields 66.95 gallons per year fuel savings per vehicle. Each gallon of gasoline is equivalent to 123,905 BTUs (U.S. DOE, 2002c). For driver training, we assumed one vehicle per workshop attendee, yielding savings of 8.3 million source BTUs per attendee. For maintenance training, we assumed 10 vehicles per workshop attendee, which yields savings of 83.0 million BTUs per attendee. In the program savings calculations, we used the savings number for maintenance training.

\section{RETROFITS}

We report energy-savings estimates for retrofits in residential, commercial, two types of institutional (education and hospital), and industrial applications. We use two indicators for retrofits: the number of buildings retrofitted and the square footage retrofitted. We describe the development of the energy-savings coefficients used with each indicator separately. 


\section{Indicator 1: Number of buildings retrofit, by sector}

\section{Residential}

We obtained primary energy savings per house from residential retrofits, by four regions of the country from Schweitzer and Eisenberg (2002). These savings estimates were for actions that could be taken by the Weatherization Assistance Program (WAP), at costs ranging from $\$ 1100$ to over $\$ 2700$ per house, depending on the region. From Cohen et al. (1991), the average extent of residential retrofit expenses per home is $\$ 750.73$ in 2000 prices. We used this nationwide average retrofit cost to reduce proportionally the projected energy savings per house in the WAP weatherizations reported in Schweitzer and Eisenberg. These calculations yielded:

Northeast: 12.54 million source BTUs/house

South: $\quad 12.67$ million source BTUs/house

Midwest: 21.00 million source BTUs/house

West: $\quad 11.82$ million source BTUs/house

We used an unweighted, nationwide average savings of 14.51 million source BTUs per house for the coefficient value of a residential retrofit.

\section{Commercial}

From the 1999 Commercial Building Energy Consumption Survey (U.S. DOE 2002a), we used 14,500 square feet and 2574.0 million source BTUs as the average size and annual energy use of a commercial building. From Greely et al. (1990) and Coates (1995), we obtained an average of 18.8 percent savings in retrofits for commercial buildings. The product of the energy use and savings figures yields a coefficient of 483.9 million source BTUs of energy savings per commercial retrofit project.

\section{Education}

The 1999 CBECS reports the average size of schools as 26,400 square feet, and Greely et al. (1990) cite the measured energy savings of the retrofits in schools as 0.016 million source BTUs per square foot of floor space. The product of these two numbers is 422.4 million source BTUs per retrofit project.

\section{Hospitals}

According to the 1999 CBECs, the average size of a hospital is 228,540 square feet. Lew and Wang (1998) report the annual energy savings per retrofit in hospitals as 0.041 million source BTUs per square foot. The product of these two numbers gives an energy-savings coefficient value of 9,370.1 million source BTUs per retrofit project. 


\section{Industrial}

Rutgers University (1999) publishes the annual reports of the Industrial Assessment Center (IAC) Program. Table 18 of this document provides data on average implemented energy and cost savings per assessment for that year. The average implemented energy savings in 1999 was 4,044 million source BTUs per assessment.

\section{Indicator 2: Floor space of buildings retrofit, by sector \\ Residential}

We use an average residence size of 1,600 square feet. Dividing the average energy savings per building noted above by this average house size, we obtain a coefficient value of 0.008 million source BTUs per square foot.

\section{Commercial}

We divide the 483.9 million source BTUs of energy savings per commercial building by the 14,500 square footage figure for the average commercial building to obtain a coefficient value of 0.033 million source BTUs per square foot.

\section{Education}

As noted above, Greely et al. (1990) report that school retrofits yield an average savings of 0.016 million source BTUs per square foot of floor space.

\section{Hospital}

As note above, Lew and Wang (1990) report that retrofits in hospitals result in average savings of 0.041 million source BTUs per square foot.

\section{ENERGY AUDITS}

We estimated energy savings from audits for the residential, commercial, institutional, and industrial sectors. We use three indicators for audits: the number of buildings audited, the floor space audited, and the projected energy savings of the audit. Ideally, the responding states would not report both audits and retrofits performed on the same structures. However, it is possible that such double-counting might have occurred in some instances, which would result in some over-statement of savings. This issue will be addressed by refined instructions in future data collection efforts. 


\section{Indicator 1: Number of audits performed, by sector}

\section{Residential}

Estimates of energy savings per house from audits appear to have been improving over time, rising from 5 million source BTUs in 1981-82 (Clinton et al. 1986) to 6.6 million source BTUs in 1996 (Haberl et al. 2000). Extrapolating this trend, we used a figure of 6.8 million source BTUs per house for savings from current residential audits.

\section{Commercial}

The per-unit savings estimate for commercial retrofits listed previously (483.9 million source BTUs per project) provides the base for our estimate of savings associated with energy audits in the Commercial sector. We applied an adjustment factor of 0.50 to the retrofit number, based on the conservative assumption that only half of the recommended measures would be installed. This yields a savings coefficient of 242.0 million source BTUs per audit project.

\section{Institutional}

The per-unit savings estimates for education and health facilities presented in the Retrofits section (above) provide the basis for the Institutional Audit savings multipliers used in this study. Each of the coefficients used for Retrofits was multiplied by an adjustment factor of 0.50 , based on the assumption that only half of audit-recommended measures are actually installed. For educational facilities, this yields a savings coefficient of 211.2 million source BTUs per building. For hospitals, the coefficient is 4,685.1 million source BTUs per building. To get a multiplier that applies to the entire Institutional sector, a simple average was calculated from the per-building numbers given above. The resulting per-unit savings multiplier is $2,448.2$ million source BTUs per building.

\section{Industrial}

For our estimate of expected savings per industrial audit, we used the figure of 4044 million source BTUs from the IAC evaluation. That number represents the average savings achieved by participating industries as a result of taking various actions recommended in the assessments of energy-saving opportunities performed under the IAC program.

\section{Indicator 2: Floor space audited, by sector}

\section{Residential}

We divide the 6.8 million source BTUs saved per audit by the 1600 square feet of the average dwelling unit to obtain 0.00425 million source BTUs per square foot. 


\section{Commercial}

We divide the 242 million source BTUs of energy savings per commercial audit by the 14,500 square feet of the average sized commercial building to obtain 0.0167 million source BTUs per square foot.

\section{Institutional}

The per-square-foot savings estimates for education and health facilities presented in the Retrofits section provide the basis for the Institutional Audit savings multipliers presented here. Each of the coefficients used for Retrofits was multiplied by an adjustment factor of 0.50 , as explained above. This yields savings coefficients of 0.008 million source BTUs per square foot for educational facilities and 0.0205 million source BTUs per square foot for hospitals. To get a single multiplier for the entire Institutional sector, a simple unweighted average was calculated. The resulting per-unit savings multiplier is 0.0143 million source BTUs per square foot (0.008 million source BTUs plus 0.0205 million source BTUs divided by 2).

\section{Indicator 3: Projected energy savings, by sector}

Where the states provided their own estimates of audit-related energy savings, those numbers were used, after adjusting them downward to reflect the expectation that only half of the recommended measures would be installed and that only a portion of the projected savings (60 percent in the residential sector and 90 percent elsewhere) actually would be realized by the measures taken. Based on those expectations, we multiplied state-projected savings by adjustment factors of 0.3 in the residential sector and 0.45 in all other sectors.

\section{PROCUREMENT OF ENERGY-EFFICIENT PRODUCTS}

We estimated savings from the procurement of more energy-efficient HVAC equipment, office equipment, and vehicles in government agencies.

\section{Indicator: Number of units purchased, by type}

\section{HVAC equipment}

We assumed that commercial buildings of four general types (education; office; public assembly; and public order and safety) would primarily be affected by government procurement programs. According to the 1995 CBECs, the average energy consumption for each building of such types is 3122.6 million source BTUs, and $35.7 \%$ of that (1,114.8 million source BTUs) is used for HVAC purposes. Using data from a recent study of emerging technologies (Nadel et al. 1998) and from web-based savings calculations provided by ENERGYSTAR (U.S. EPA 2002b) and the Federal Energy Management Program (U.S. DOE 2002b), we estimated that savings from the procurement of highly efficient HVAC equipment would amount to $20 \%$ of current per- 
building consumption for HVAC purposes, or 223.0 million source BTUs annually per unit purchased.

\section{Office equipment}

Information on energy savings from energy-efficient (ENERGY STAR) office equipment was taken from the ENERGY STAR website (2000). We used an unweighted average kWh savings for computer and monitor, scanner, printer, fax machine, and copier. Converting that average to source energy yields an average of 2.56 million source BTUs per unit of office equipment.

\section{Vehicles}

For the energy savings resulting from the purchase of a more energy-efficient vehicle for a government agency's fleet, we used the savings per vehicle estimated for vehicle maintenance training, which is 8.5 million source BTUs per vehicle per year (see Workshops and Training section, above).

\section{TECHNICAL ASSISTANCE}

\section{Indicator: Number of recommendations made for energy-efficiency measures or strategies, by sector}

\section{Residential}

For residential technical assistance, we reviewed individual measures across various regions of the country, reported in tables in Schweitzer and Eisenberg (2002). An unweighted average of the savings associated with wall insulation, attic insulation, air sealing, and refrigerator replacement measures gives us a coefficient of 9.0 million source BTUs in energy savings per recommendation.

\section{Commercial and Industrial}

For technical assistance in the commercial and industrial sectors, we used half of the corresponding energy savings from retrofits in those sectors. Thus, the savings coefficients for the commercial and industrial sectors are 217.3 million source BTUs per recommendation and 2022 million source BTUs per recommendation, respectively.

\section{LOANS AND GRANTS}

Energy-savings coefficients were calculated separately for loan and grant programs. 


\section{Loan Programs}

\section{Indicator: Monetary value of loans given, by sector}

The Oregon Office of Energy (2000) reported \$267 million in outlays in its loan program in 1999, and estimated 6.067 trillion source BTUs in associated savings. Dividing 6.067 trillion source BTUs by $\$ 267$ million dollars yields a coefficient value of 0.0227 million source BTUs per dollar.

NYSERDA (2001) reported receiving 62 applications for over \$5 million in energy efficiency capital improvements. Funds had been encumbered for 47 of those. Using the $\$ 5$ million figure, $47 / 62$ of that amount would be $\$ 3.79$ million obligated. The same report claimed 3.5 million $\mathrm{kWh}$ in anticipated electricity savings from its loan fund. Converting the $\mathrm{kWh}$ to source BTUs gives anticipated savings of 38,091 million source BTUs. The calculation $(38,091$ million source BTUs/\$3,790,000) yields 0.0101 million BTUs per dollar for loans.

Averaging the Oregon and New York savings estimates, weighting them equally, gives an overall coefficient of 0.0164 million source BTUs per dollar. The same coefficient was used in all sectors for which loan programs were evaluated: residential, commercial, industrial, and institutional.

\section{Grants Programs}

\section{Indicator: Monetary value of grants given, by sector}

Louisiana's Department of Natural Resources(2001) achieved energy savings of 26,000 million source BTUs as a result of Institutional Conservation Program grants totaling $\$ 1,053,000$. The calculation $(26,000$ million source BTUs $/ \$ 1,053,000)$ yields a coefficient value of 0.0247 million source BTUs per dollar for those grants.

A private California company, drawing primarily from grants to schools, reported 398 million kWh in energy savings from \$400 million in grants (Building Systems Engineering \& Building Systems Management, 2001). These kWh are equivalent to 4.331 trillion source BTUs. Dividing savings by expenditures yields a coefficient value of 0.01083 million source BTUs per dollar of grant.

Averaging the Louisiana and California coefficients, with equal weights, gives an overall coefficient value for grants programs of 0.0178 million source BTUs per dollar. The same coefficient was used in all sectors for which grant programs were evaluated: residential, commercial, industrial, and institutional. 


\section{CODES AND STANDARDS}

\section{Indicator: Number of energy-consuming systems or technologies for which codes and standards are adopted at state or local level, by sector}

\section{Residential}

The per-unit savings multiplier describes the amount of energy saved — statewide - as a result of a state's adoption of a code or standard for a single type of energy-consuming system or technology (i.e., building shell, lighting, HVAC, or appliances). The first step in calculating this coefficient was to approximate potential annual nationwide savings from adopting the 1993 Model Energy Code (MEC) in areas where it is not currently in effect. Based on a report from the Alliance To Save Energy (Jones, Norland, and Prindle 1998), this number is approximately $7,424,000$ million source BTUs for single-family and multi-family units combined.

The additional potential nationwide savings associated with adoption of the 1998 International Energy Conservation Code (IECC) was calculated by multiplying average household savings associated with use of this code (generated using the REM energy analysis software system) by total housing starts. This amounts to approximately 673, 590 million source BTUs.

Potential nationwide savings from energy-efficient appliance codes (regardless of the type of building in which the appliance is placed) were calculated by taking per-unit savings for each of a common set of devices, multiplying per-unit savings for each device by the number sold nationwide, summing all the savings, and dividing by the number of devices involved. This yields average nationwide savings for a single device. The four devices considered here were refrigerator, clothes washer, dishwasher, and water heater. Savings for each device were taken from a number of recent studies (Nadel and Goldstein 1996, Nadel et. al. 1998, Wenzel et. al. 1997). Annual sales for each device were provided by the Gas Appliance Manufacturers Association (1999). Based on these data, average annual nationwide savings for one device (for all building types) equals 21,529,130 million source BTUs divided by 4, or 5,382,283 million source BTUs.

The appliance savings shown above were apportioned among residential and nonresidential buildings, based on the assumption that $85 \%$ of the four appliances would be placed in residential buildings and the remaining $15 \%$ of those appliances would be in non-residential buildings. Accordingly, $85 \%$ of the savings would occur in the residential sector and $15 \%$ in the non-residential sector. Annual residential savings per device (nationwide) equals 5,382,283 million source BTUs times 0.85, which amounts to 4,574,941 million source BTUs.

To calculate nationwide savings from all the codes efforts listed above (MEC 93, 1998 IEEC, and appliance standards), we summed the following: (1) potential savings from MEC 93, multiplied by 0.85 (to reflect the likelihood that about $85 \%$ of residential construction, on average, would be covered by the code) and multiplied by a code compliance factor of 0.80 ; 
(2) potential 
savings from the 1998 IECC, multiplied by 0.425 (to reflect the likelihood that only half the adopting states would adopt this code and that $85 \%$ of the residential construction, on average, would be covered) and multiplied by the 0.80 code compliance factor; and (3) residential-sector savings from appliance standards for a single device. This amounts to 5,048,320 million source BTUs plus 229,021 million source BTUs plus 4,574,941 million source BTUs, or 9,852,282 million source BTUs.

The above number was divided by four to get average annual nationwide savings from a single type of code (since, between them, the above codes cover the four elements of building shell, lighting, HVAC, and appliances). This equals 9,852,282 million source BTUs divided by 4 , or 2,463,071 million source BTUs per code element. Then, this number was multiplied by each state's proportion of total U.S. population to get approximate per-unit energy savings weighted by state population yielding a different coefficient for each state. Because each state's population is roughly proportional to home construction and appliance sales, this adjustment gives much more accurate savings than would attributing one-fiftieth of total national savings to each state.

\section{Commercial and Institutional}

This coefficient describes the amount of energy saved by a given state as a result of its adoption of the ASHRAE/IES90.1-1989 code and energy-efficient appliance codes. Potential nationwide savings associated with adoption of the ASHRAE/IES code were calculated by multiplying average per-building savings associated with use of this code by total building starts. Average per-building savings, estimated by ORNL staff from information on all U.S. climate zones and all commercial/institutional building types, amount to approximately 226.4 million source BTUs annually. The average number of commercial/institutional buildings constructed from 1990-1999 was 69,000 per year, according to the 1999 Commercial Building Energy Consumption Survey (CBECS). Therefore, potential nationwide savings from following the ASHRAE/IES90.1-1989 code is 226.4 million source BTUs times 69,000, or 15,621,600 million source BTUs.

Potential nationwide savings from energy-efficient appliance codes were calculated by taking per-unit savings for the same four devices discussed in the Residential section, multiplying per-unit savings for each device by the number sold nationwide, summing all the savings, and then dividing by the number of devices involved. As described above, this yields average nationwide savings for a single device of 5,382,283 million source BTUs. It is assumed that $15 \%$ of the appliances will be placed in non-residential buildings, so annual commercial/institutional savings per device (nationwide) equals 5,382,283 million source BTUs times 0.15 , or 807,342 million source BTUs.

Nationwide savings from the ASHRAE/IES90.1-1989 code and appliance standards combined were calculated by summing the following: (1) potential savings from the commercial code, multiplied by 0.85 (to reflect the likelihood that about $85 \%$ of commercial construction, on average, would be covered by the code) and multiplied by a code compliance factor of 0.80 ; and 
(2) commercial/institutional-sector savings from appliance standards for a single device. This amounts to 10,622,688 million source BTUs plus 807,342 million source BTUs, or 11,430,030 million source BTUs.

The above number was divided by four to get average annual nationwide savings from a single type of code. This equals $11,430,030$ million source BTUs divided by 4, or 2,857,508 million source BTUs. This number was multiplied by each state's proportion of total U.S. population to get approximate per-unit energy savings.

\section{RATING AND LABELING}

\section{Indicator: Number of energy-consuming devices for which rating and labeling systems are endorsed by the state}

The energy-savings coefficient describes the amount of energy saved—statewide — as a result of a state's endorsement of a rating and labeling system for a single type of energyconsuming device. Because the ENERGY STAR program is the biggest and most successful rating and labeling program operating at this time and many states use SEP funds to encourage participation in the ENERGY STAR program, we used the savings associated with the ENERGY STAR program to represent the savings achieved by all state rating and labeling efforts.

We began by identifying a typical set of 15 energy-consuming devices for which energyefficient rating and labeling systems could be developed and calculating the difference in annual energy use between an ENERGY STAR unit and a typical unit for each type of device. Then, we multiplied the number of ENERGY STAR units sold annually for each of the 15 devices (nationwide) by the unit-savings for each device and summed the 15 products to get total national annual savings for the entire set (Webber, Brown, and Koomey 2000). Total savings calculated in this manner amounted to 134,314,346 million source BTUs for 2000.

The total savings number given above was divided by 15 to get average annual savings for a single type of ENERGY STAR device: 8,954,290 million source BTUs. This savings number was adjusted downward by multiplying by an "attribution factor" of 0.10 , which approximates the proportion of ENERGY STAR purchases made as a result of state encouragement (Feldman and Tannenbaum 2000)]. Accordingly, the adjusted nationwide savings number per device is 895,429 million source BTUs per year.

For each state, per-unit energy savings were estimated by multiplying the nationwide savings number (895,429 million source BTUs) by that state's proportion of total U.S. population. This means that each state has a unique coefficient. Because each state's population is roughly proportional to equipment sales, this adjustment will give much more accurate savings than would attributing one-fiftieth of total national savings to each state. 


\section{HOME ENERGY RATING SYSTEMS (HERS) AND ENERGY-EFFICIENCY MORTGAGES (EEMs)}

\section{Indicator: Number of energy-efficiency mortgages issued in conjunction with a Home Energy Rating System}

Information was taken from a study by Louisiana's Department of Natural Resources of its proposed Energy Rated Homes of Louisiana Program (Applied Technology Research Corporation 1995). Their study offered several scenarios composed of different energy-savings percentages, all based on a $5 \%$ market penetration assumption for the energy-efficiency mortgage. The savings assumptions were 20,30 and 40 percent. We used the 20 percent savings assumption as being the most reasonable. This savings level yielded an estimate of 37.6 million source BTUs per house. An alternative estimate (Residential Energy Services Network 2001) was available, but that estimate of 70.625 million source BTUs per house was nearly equivalent to the 40 percent savings scenario of the Louisiana study. Accordingly, we chose to use the coefficient of 37.6 million source BTUs savings per house.

\section{INCENTIVES}

\section{Indicator: Monetary value of rebates provided, by sector}

Pacific Gas and Electric Company (2001) reported achieving energy savings of 254 Million kWh from rebates to business customers for lighting, refrigerators, air conditioning, and food service equipment. These savings are equivalent to 2.764 trillion source BTUs. The costs were reported at $\$ 19$ million. The calculation (2.764 trillion source BTUs/ $\$ 19,000,000)$ yields 0.145 million source BTUs per dollar. The same coefficient was used in all sectors for which rebate programs were evaluated: residential, commercial, industrial, and institutional.

\section{INTEREST SUBSIDIES}

\section{Indicator: Monetary value of interest subsidies provided, by sector}

No direct information was available on interest subsidies. On the presumption that the energy savings per dollar of expenditure for this type program would approximate that of loans, we used the same coefficient of 0.0164 million source BTUs per dollar. The same coefficient was used in all sectors for which interest subsidy programs were evaluated: residential, commercial, industrial, and institutional. 


\section{TAX CREDITS}

\section{Indicator: Monetary value of tax credits given, by sector}

The Oregon Office of Energy (2000) reported a number of tax credits at various maximum credit levels: 20,613 at the $\$ 1500$ credit level for renewable resources; 42,636 at $\$ 350$ for appliances; 20 at $\$ 1500$ for alternative fuel vehicles ( $\$ 750$ for vehicles and $\$ 750$ for a recharging system); and 138 at $\$ 250$ for energy-efficient ducts. The total cumulative values of credits given over the life of the program in each category were: $\$ 21,650,542$ for renewables, $\$ 6,267,451$ for appliances, $\$ 27,920$ for alternative fuel vehicles, and $\$ 26,609$ for ducts. The total cost of tax credits is $\$ 27,972,522$. These were estimated to have saved 53.4 million $\mathrm{kWh}$, (581,152 million source BTUs), 889,000 therms of natural gas (88,900 million source BTUs), and 11,000 gallons (1,529 million source BTUs) of fuel oil. This amounts to savings of 671,581 million source BTUs in total.

The calculation $(671,581$ million source BTUs/\$27,972,522) yields a coefficient value of 0.024 million source BTUs per dollar. The same coefficient was used in all sectors for which tax credit programs were evaluated: residential, commercial, industrial, and institutional.

\section{TRAFFIC SIGNALS AND CONTROLS}

\section{Indicator: Number of energy-efficient traffic signals installed}

There is a national effort to replace old traffic signals with light-emitting diode (LED) technology. The LEDs produce colored light that does not have to be filtered. Energy savings are on the order of 80-90 percent. A 12-inch LED signal uses 25 Watts or less, compared to 150 Watts for an incandescent bulb (Consortium for Energy Efficiency 2001). The energy savings achieved are 125 Watts per LED and 375 Watts per signal (three lights). Energy savings per traffic signal per year is $3,285 \mathrm{kWh}$, which is 35.75 million source BTUs.

\section{CARPOOLS AND VANPOOLS}

\section{Indicator: Number of new carpools and vanpools formed}

The U.S. Environmental Protection Agency has an on-line commuter model (U.S. EPA 2002a) to help communities estimate energy savings and emissions reductions associated with changing modes of personal travel. The commuter model has default parameters for small, medium, and large city sizes. We chose a medium size city for this analysis. Parameters were taken from the model, unless otherwise noted. 


\section{Carpools}

average size of a carpool

average length of a single-occupant one-way work trip

average length of a carpool one-way work trip (ORNL estimate)

number of days of carpool trips (ORNL estimate)

avg automobile fuel efficiency, city driving (ORNL estimate)

Btu/gallon of gasoline (from U.S. DOE, 2002c)

average carpool energy savings
2.2 persons

11.4 miles

15 miles

250

$20 \mathrm{mpg}$

123,905

31.2 million source BTUs

Annual energy use for a single occupant was calculated by: (1) doubling the one-way mileage shown above to get the length of a round trip; (2) multiplying that number by the annual number of days during which work trips are taken; (3) dividing that number by the average number of miles per gallon; and (4) multiplying that by the number of BTUs in a gallon of gasoline. These calculations yield an average energy use of 35.3 million source BTUs for a single occupant work trip. Annual energy use by a carpool was calculated in the same way, using all the same numbers except the average length of a work trip, which is longer for carpools because of the need to pick up extra passengers. These calculations show that annual average energy use by a carpool is 46.5 million source BTUs. To calculate the amount of energy saved by a carpool, single-occupant energy use was multiplied by 2.2 (the number of occupants in an average carpool) to show the amount of energy (77.7 million source BTUs) that would be used by carpo01 occupants if they were driving to work alone. Then, the average carpool energy consumption was subtracted from the number of yield average annual savings of 31.2 million source BTUs (77.7 minus 46.5).

\section{Vanpools}

average size of a vanpool

average length of a single-occupant one-way work trip

average length of a vanpool one-way work trip (ORNL estimate)

number of days of vanpool trips (ORNL estimate)

avg automobile fuel efficiency, city driving (ORNL estimate)

avg van fuel efficiency, city driving (ORNL estimate)

Btu/gallon of gasoline (from U.S. DOE, 2002c)

average vanpool energy savings
6 persons

11.4 miles

17.7 miles

250

$20 \mathrm{mpg}$

$10 \mathrm{mpg}$

123,905

102.2 million source BTUs

Annual energy use for a single occupant was calculated in the manner described above under Carpools, showing an average annual energy use of 35.3 million source BTUs. Annual energy use by a vanpool was calculated in an identical manner, except that the average length of a work trip is longer than for single occupants and for carpools because of the extra passengers involved and the average fuel efficiency is lower because of the larger vehicle required. The calculations show that annual average energy use by a vanpool is 109.7 million source BTUs. To calculate the amount of energy saved by a vanpool, single-occupants energy use was multiplied by 6 (the number of occupants in an average vanpool) to show the amount of energy (211.9 
million source BTUs) that would be used by vanpool occupants if they were driving to work alone. Then, the average vanpool energy consumption was subtracted from the number to yield average annual savings of 102.2 million source BTUs (211.9 minus 109.7).

Our coefficient value for carpool and vanpool programs is an unweighted average of the two savings values reported above, 66.7 million source BTUs. 


\section{APPENDIX B. SAVINGS CALCULATIONS}

The following tables show the key inputs used to calculate energy and cost savings for each program area for which savings coefficients could be developed. In nearly all cases, the number of inputs reported for each indicator (e.g., workshop attendees, buildings retrofit, monetary value of grants given) is multiplied by the average savings per unit of input to yield annual energy savings (in million source BTUs) ${ }^{7}$. The energy-savings number is then multiplied by $\$ 6.20$ (the average cost of a million source BTUs) to get annual cost savings. Where there are multiple energy-consuming sectors within a single program area, the number of activities and a savings coefficient are given for each. For those program areas where energy savings can be estimated by more than one indicator, each indicator is shown separately, and total savings are calculated by summing the savings for all of them ${ }^{8}$. In the interest of simplicity, the numbers of inputs shown in these tables represent totals for all responding states combined, even though the spreadsheets used to calculate energy savings actually generated savings numbers for each state separately and then summed the results.

\section{WORKSHOPS AND TRAINING}

Indicator: Number of people attending workshops, by sector

\begin{tabular}{|c|c|c|c|c|}
\hline Sector & $\begin{array}{l}\text { Total number } \\
\text { of attendees }\end{array}$ & $\begin{array}{l}\text { Average savings } \\
\text { per attendee } \\
\text { (million source } \\
\text { BTUs) }\end{array}$ & $\begin{array}{c}\text { Annual energy } \\
\text { savings } \\
\text { (million source } \\
\text { BTUs) }\end{array}$ & $\begin{array}{c}\text { Annual cost } \\
\text { savings (\$) }\end{array}$ \\
\hline Commercial Buildings & 5,612 & 324.4 & $1,820,533$ & $11,287,303$ \\
\hline Vehicles & 2,997 & 83 & 248,751 & $1,542,256$ \\
\hline Total savings & & & $2,069,284$ & $12,829,559$ \\
\hline
\end{tabular}

${ }^{7}$ The only exception is in the case of Energy Audits, where one of the indicators used is projected energy savings. In that case, an estimate of savings is provided by the reporting states, and that number is multiplied by an adjustment factor that takes into account installation and savings-realization rates.

${ }^{8}$ The savings calculated from multiple indicators can be summed without double-counting outcomes because either the indicators apply to mutually exclusive activities (in the case of Loans and Grants) or the inputs for only a single indicator are used for each state (which is the case for Retrofits and Energy Audits). 


\section{RETROFITS}

Indicator 1: Number of buildings retrofit, by sector

\begin{tabular}{|c|c|c|c|c|}
\hline Sector & $\begin{array}{l}\text { Total number } \\
\text { of buildings } \\
\text { retrofit }\end{array}$ & $\begin{array}{l}\text { Average savings } \\
\text { per building } \\
\text { (million source } \\
\text { BTUs) }\end{array}$ & $\begin{array}{c}\text { Annual energy } \\
\text { savings } \\
\text { (million source } \\
\text { BTUs) } \\
\end{array}$ & $\begin{array}{l}\text { Annual cost } \\
\text { savings (\$) }\end{array}$ \\
\hline Residential & 3,490 & 14.5 & $50,605.0$ & 313,751 \\
\hline Commercial & 91 & 483.9 & $44,034.9$ & 273,016 \\
\hline Industrial & 24 & 4,044 & $97,056.0$ & 601,747 \\
\hline Total savings & & & $191,695.9$ & $1,188,514$ \\
\hline
\end{tabular}

Indicator 2: Floor space of buildings retrofit, by sector

\begin{tabular}{|c|c|c|c|c|}
\hline Sector & $\begin{array}{l}\text { Total floor } \\
\text { space retrofit } \\
\text { (square feet) }\end{array}$ & $\begin{array}{c}\text { Average savings } \\
\text { per square foot } \\
\text { (million source } \\
\text { BTUs) }\end{array}$ & $\begin{array}{c}\text { Annual energy } \\
\text { savings } \\
\text { (million source } \\
\text { BTUs) } \\
\end{array}$ & $\begin{array}{c}\text { Annual cost } \\
\text { savings (\$) }\end{array}$ \\
\hline Residential & $27,378,400$ & 0.008 & $219,027.2$ & $1,357,969$ \\
\hline Commercial & $5,119,822$ & 0.033 & $168,954.1$ & $1,047,516$ \\
\hline Education & $19,020,817$ & 0.016 & 304,330 & $1,886,865$ \\
\hline Hospitals & $2,108,721$ & 0.041 & 86,458 & 536,037 \\
\hline Total savings & & & $778,769.3$ & $4,828,387$ \\
\hline
\end{tabular}

Combined savings from Indicators 1 and 2

\begin{tabular}{|c|c|c|}
\hline Indicator & $\begin{array}{l}\text { Annual energy savings } \\
\text { (million source BTUs) }\end{array}$ & Annual cost savings (\$) \\
\hline $\begin{array}{l}\text { 1. Number of buildings } \\
\text { retrofit }\end{array}$ & $191,695.9$ & $1,188,514$ \\
\hline 2. Floor space retrofit & $778,769.3$ & $4,828,387$ \\
\hline Total savings & $970,465.2$ & $6,016,901$ \\
\hline
\end{tabular}




\section{ENERGY AUDITS}

Indicator 1: Number of audits performed, by sector

\begin{tabular}{|c|c|c|c|c|}
\hline Sector & $\begin{array}{c}\text { Total number } \\
\text { of audits } \\
\text { performed }\end{array}$ & $\begin{array}{l}\text { Average savings } \\
\text { per audit (million } \\
\text { source BTUs) }\end{array}$ & $\begin{array}{c}\text { Annual energy } \\
\text { savings (million } \\
\text { source BTUs) }\end{array}$ & $\begin{array}{c}\text { Annual cost } \\
\text { savings }(\$)\end{array}$ \\
\hline Residential & 36 & 6.8 & 244.8 & 1,518 \\
\hline Commercial & 55 & 242 & 13,310 & 82,522 \\
\hline Industrial & 8 & 4,044 & 32,352 & 200,582 \\
\hline Total savings & & & $45,906.8$ & 284,622 \\
\hline
\end{tabular}

Indicator 2: Floor space audited, by sector

\begin{tabular}{|c|c|c|c|c|}
\hline Sector & $\begin{array}{l}\text { Total floor } \\
\text { space retrofit } \\
\text { (square feet) }\end{array}$ & $\begin{array}{l}\text { Average savings per } \\
\text { square foot (million } \\
\text { source BTUs) }\end{array}$ & $\begin{array}{c}\text { Annual energy } \\
\text { savings } \\
\text { (million source } \\
\text { BTUs) }\end{array}$ & $\begin{array}{c}\text { Annual cost } \\
\text { savings (\$) }\end{array}$ \\
\hline Residential & $8,968,400$ & 0.004 & $35,873.6$ & 222,416 \\
\hline Commercial & 674,348 & 0.0167 & $11,261.6$ & 69,822 \\
\hline Institutional & $6,538,500$ & 0.0143 & $93,500.6$ & 579,703 \\
\hline Total savings & & & $140,635.8$ & 871,941 \\
\hline
\end{tabular}

Indicator 3: Projected energy savings, by sector

\begin{tabular}{|c|c|c|c|c|}
\hline Sector & $\begin{array}{c}\text { Total projected } \\
\text { savings (million } \\
\text { source BTUs) }\end{array}$ & $\begin{array}{l}\text { Adjustment } \\
\text { factor }\end{array}$ & $\begin{array}{c}\text { Annual energy } \\
\text { savings (million } \\
\text { source BTUs) }\end{array}$ & $\begin{array}{c}\text { Annual cost } \\
\text { savings (\$) }\end{array}$ \\
\hline Residential & 12.5 & 0.3 & 3.75 & 23 \\
\hline Commercial & $562,855.5$ & 0.45 & $253,285.0$ & $1,570,367$ \\
\hline Industrial & 35,000 & 0.45 & 15,750 & 97,650 \\
\hline Institutional & $6,441,880$ & 0.45 & $2,898,846$ & $17,972,845$ \\
\hline Total savings & & & $3,167,884.75$ & $19,640,885$ \\
\hline
\end{tabular}




\section{ENERGY AUDITS (continued)}

\section{Combined savings from Indicators 1, 2, and 3}

\begin{tabular}{lrr}
\hline \multicolumn{1}{c}{ Indicator } & $\begin{array}{c}\text { Annual energy savings } \\
\text { (million source BTUs) }\end{array}$ & $\begin{array}{c}\text { Annual cost savings } \\
(\$)\end{array}$ \\
\hline 1. Number of audits performed & $45,906.8$ & 284,622 \\
2. Floor space audited & $140,635.8$ & 871,941 \\
3. Projected energy savings & $3,167,884.75$ & $19,640,885$ \\
\hdashline$\quad \ldots \ldots \ldots \ldots \ldots \ldots$ \\
$\quad$ Total savings & $3,354,427.4$ & $20,797,448$ \\
\hline
\end{tabular}

\section{PROCUREMENT}

Indicator: Number of units purchased, by type

\begin{tabular}{|c|c|c|c|c|}
\hline Type of Purchase & $\begin{array}{c}\text { Total number } \\
\text { of units } \\
\text { purchased }\end{array}$ & $\begin{array}{l}\text { Average savings } \\
\text { per unit (million } \\
\text { source BTUs) }\end{array}$ & $\begin{array}{c}\text { Annual energy } \\
\text { savings (million } \\
\text { source BTUs) }\end{array}$ & $\begin{array}{c}\text { Annual cost } \\
\text { savings (\$) }\end{array}$ \\
\hline HVAC equipment & 98 & 223 & 21,854 & 135,495 \\
\hline Office equipment & 8,927 & 2.56 & 22,853 & 141,689 \\
\hline Vehicles & 607 & 8.5 & 5,160 & 31,989 \\
\hline Total savings & & & 49,867 & 309,173 \\
\hline
\end{tabular}


TECHNICAL ASSISTANCE

Indicator: Number of recommendations for energy-efficiency measures or strategies, by sector

\begin{tabular}{|c|c|c|c|c|}
\hline Sector & $\begin{array}{l}\text { Total number of } \\
\text { recommendations }\end{array}$ & $\begin{array}{l}\text { Average savings per } \\
\text { recommendation } \\
\text { (million source BTUs) }\end{array}$ & $\begin{array}{l}\text { Annual energy } \\
\text { savings } \\
\text { (million source } \\
\text { BTUs) }\end{array}$ & $\begin{array}{l}\text { Annual cost } \\
\text { savings }(\$)\end{array}$ \\
\hline Residential & 18,017 & 9 & 162,153 & $1,005,349$ \\
\hline Commercial & 604 & 217.3 & 131,249 & 813,745 \\
\hline Industrial & 140 & 2,022 & $287,020 *$ & $1,779,524$ \\
\hline Total savings & & & 580,422 & $3,598,618$ \\
\hline
\end{tabular}

\section{LOANS AND GRANTS}

Indicator for Loan Programs: Monetary value of loans given, by sector

\begin{tabular}{|c|c|c|c|c|}
\hline Sector & $\begin{array}{c}\text { Total monetary } \\
\text { value of loans } \\
\text { given }\end{array}$ & $\begin{array}{l}\text { Average savings } \\
\text { per dollar of } \\
\text { loan (million } \\
\text { source BTUs) }\end{array}$ & $\begin{array}{l}\text { Annual energy } \\
\text { savings (million } \\
\text { source BTUs) }\end{array}$ & $\begin{array}{c}\text { Annual cost } \\
\text { savings }(\$)\end{array}$ \\
\hline Residential & $11,664,377$ & 0.0164 & 191,296 & $1,186,034$ \\
\hline Commercial & 975,724 & 0.0164 & 16,002 & 99,212 \\
\hline Industrial & $4,998,569$ & 0.0164 & 81,977 & 508,254 \\
\hline Institutional & $6,173,354$ & 0.0164 & 101,243 & 627,707 \\
\hline Total savings & & & 390,518 & $2,421,207$ \\
\hline
\end{tabular}


LOANS AND GRANTS (continued)

Indicator for Grants Programs: Monetary value of grants given, by sector

\begin{tabular}{|c|c|c|c|c|}
\hline Sector & $\begin{array}{l}\text { Total monetary } \\
\text { value of grants } \\
\text { given }\end{array}$ & $\begin{array}{l}\text { Average savings } \\
\text { per dollar of } \\
\text { loan (million } \\
\text { source BTUs) }\end{array}$ & $\begin{array}{c}\text { Annual energy } \\
\text { savings (million } \\
\text { source BTUs) }\end{array}$ & $\begin{array}{l}\text { Annual cost } \\
\text { savings (\$) }\end{array}$ \\
\hline Residential & $13,873,541$ & 0.0178 & 246,949 & $1,531,084$ \\
\hline Commercial & $1,782,556$ & 0.0178 & 31,729 & 196,723 \\
\hline Industrial & $4,777,651$ & 0.0178 & 85,042 & 527,262 \\
\hline Institutional & $5,980,598$ & 0.0178 & $\begin{array}{l}106,455 \\
106\end{array}$ & $\begin{array}{l}660,019 \\
660.6\end{array}$ \\
\hline Total savings & & & 470,175 & $2,915,088$ \\
\hline
\end{tabular}

\section{Combined savings from Loans and Grants}

\begin{tabular}{|c|c|c|}
\hline Indicator & $\begin{array}{l}\text { Annual energy savings } \\
\text { (million source BTUs) }\end{array}$ & Annual cost savings (\$) \\
\hline Monetary value of loans & 390,518 & $2,421,207$ \\
\hline Monetary value of grants & 470,175 & $2,915,088$ \\
\hline Total savings & 860,693 & $5,336,295$ \\
\hline
\end{tabular}

\section{CODES AND STANDARDS}

Indicator: Number of systems or technologies for which codes/standards are adopted, by sector

\begin{tabular}{|c|c|c|c|c|}
\hline Sector & $\begin{array}{c}\text { Total number of } \\
\text { systems/technologies }\end{array}$ & $\begin{array}{l}\text { Average savings per } \\
\text { system/technology } \\
\text { (million source } \\
\text { BTUs)* }\end{array}$ & $\begin{array}{l}\text { Annual energy } \\
\text { savings } \\
\text { (million } \\
\text { source BTUs) }\end{array}$ & $\begin{array}{l}\text { Annual cost } \\
\text { savings }(\$)\end{array}$ \\
\hline Residential & 26 & $105,343.65$ & $2,738,935$ & $16,981,397$ \\
\hline Commercial & 19 & $158,666.9$ & $3,014,671$ & $18,690,960$ \\
\hline Institutional & 11 & $58,456.3$ & 643,019 & $3,986,717$ \\
\hline $\begin{array}{l}\text { Total } \\
\text { savings }\end{array}$ & & & $6,396,625$ & $39,659,074$ \\
\hline
\end{tabular}

*These are weighted averages based on the populations of the responding states and the number of 
systems/technologies for which codes/standards are adopted in each.

RATING AND LABELING

Indicator: Number of devices for which rating and labeling systems are endorsed

\begin{tabular}{cccc}
\hline $\begin{array}{c}\text { Total number of } \\
\text { devices }\end{array}$ & $\begin{array}{c}\text { Average savings per } \\
\text { device (million } \\
\text { source BTUs) }\end{array}$ & $\begin{array}{c}\text { Annual energy } \\
\text { savings (million } \\
\text { source BTUs) }\end{array}$ & $\begin{array}{c}\text { Annual cost savings } \\
(\$)\end{array}$ \\
\hline 82 & $30,084.23$ & $2,466,907$ & $15,294,823$ \\
\hline
\end{tabular}

*These are weighted averages based on the populations of the responding states and the number of devices for which rating and labeling systems are endorsed in each.

HOME ENERGY RATING SYSTEMS (HERS) AND ENERGY-EFFICIENCY MORTGAGES (EEMs)

Indicator: Number of energy-efficiency mortgages issued in conjunction with a Home Energy Rating System

\begin{tabular}{cccc}
\hline $\begin{array}{c}\text { Total number of } \\
\text { mortgages issued }\end{array}$ & $\begin{array}{c}\text { Average savings per } \\
\text { mortgage (million } \\
\text { source BTUs) }\end{array}$ & $\begin{array}{c}\text { Annual energy } \\
\text { savings (million } \\
\text { source BTUs) }\end{array}$ & $\begin{array}{c}\text { Annual cost savings } \\
(\$)\end{array}$ \\
\hline 8 & 37.6 & 300.8 & 1,865 \\
\hline
\end{tabular}

\section{INCENTIVES}

Indicator: Monetary value of rebates provided, by sector

\begin{tabular}{|c|c|c|c|c|}
\hline Sector & $\begin{array}{c}\text { Total monetary } \\
\text { value of rebates } \\
\text { provided }\end{array}$ & $\begin{array}{l}\text { Average savings } \\
\text { per dollar of } \\
\text { rebate (million } \\
\text { source BTUs) }\end{array}$ & $\begin{array}{l}\text { Annual energy } \\
\text { savings (million } \\
\text { source BTUs) }\end{array}$ & $\begin{array}{l}\text { Annual cost } \\
\text { savings (\$) }\end{array}$ \\
\hline Residential & 520,561 & 0.145 & 75,481 & 467,984 \\
\hline Industrial & $12,000,000$ & 0.145 & $1,740,000$ & $10,788,000$ \\
\hline Total savings & & & $1,815,481$ & $11,255,984$ \\
\hline
\end{tabular}




\section{INTEREST SUBSIDIES}

Indicator: Monetary value of interest subsidies provided, by sector

\begin{tabular}{|c|c|c|c|c|}
\hline Sector & $\begin{array}{c}\text { Total monetary } \\
\text { value of interest } \\
\text { subsidies provided }\end{array}$ & $\begin{array}{l}\text { Average savings per } \\
\text { dollar of interest } \\
\text { subsidy (million } \\
\text { source BTUs) }\end{array}$ & $\begin{array}{c}\text { Annual energy } \\
\text { savings } \\
\text { (million source } \\
\text { BTUs) }\end{array}$ & $\begin{array}{l}\text { Annual cost } \\
\text { savings (\$) }\end{array}$ \\
\hline Residential & 20,000 & 0.01635 & 327 & 2,027 \\
\hline Industrial & 58,987 & 0.01635 & 964 & 5,980 \\
\hline Total savings & & & 1,291 & 8,007 \\
\hline
\end{tabular}

\section{TAX CREDITS}

Indicator: Monetary value of tax credits given, by sector

\begin{tabular}{|c|c|c|c|c|}
\hline Sector & $\begin{array}{l}\text { Total monetary } \\
\text { value of tax } \\
\text { credits given }\end{array}$ & $\begin{array}{l}\text { Average savings } \\
\text { per dollar of tax } \\
\text { credit (million } \\
\text { source BTUs) }\end{array}$ & $\begin{array}{c}\text { Annual energy } \\
\text { savings (million } \\
\text { source BTUs) }\end{array}$ & $\begin{array}{l}\text { Annual cost } \\
\text { savings (\$) }\end{array}$ \\
\hline Residential & $3,211,654$ & 0.024 & 77,080 & 477,894 \\
\hline Commercial & 10,211 & 0.024 & 245 & 1,519 \\
\hline Industrial & 49,267 & 0.024 & 1,182 & 7,331 \\
\hline Total savings & & & 78,507 & 486,744 \\
\hline
\end{tabular}

\section{TRAFFIC SIGNALS AND CONTROLS}

Indicator: Number of energy-efficient traffic signals installed

\begin{tabular}{|c|c|c|c|}
\hline $\begin{array}{l}\text { Total number of traffic } \\
\text { signals installed }\end{array}$ & $\begin{array}{l}\text { Average savings per } \\
\text { traffic signal (million } \\
\text { source BTUs) }\end{array}$ & $\begin{array}{l}\text { Annual energy } \\
\text { savings (million } \\
\text { source BTUs) }\end{array}$ & $\begin{array}{l}\text { Annual cost } \\
\text { savings }(\$)\end{array}$ \\
\hline
\end{tabular}




\section{CARPOOLS AND VANPOOLS}

Indicator: Number of new carpools and vanpools formed

\begin{tabular}{rccc}
\hline $\begin{array}{c}\text { Total number of } \\
\text { carpools/vanpools } \\
\text { formed }\end{array}$ & $\begin{array}{c}\text { Average savings per } \\
\text { carpool/vanpool } \\
\text { (million source BTUs) }\end{array}$ & $\begin{array}{c}\text { Annual energy } \\
\text { savings (million } \\
\text { source BTUs) }\end{array}$ & $\begin{array}{c}\text { Annual cost } \\
\text { savings (\$) }\end{array}$ \\
\hline 287 & 66.7 & 19,143 & 118,686 \\
\hline
\end{tabular}





\section{APPENDIX C. METHOD FOR CALCULATING EMISSIONS REDUCTIONS}

The following steps were taken to calculate emissions reductions for those program areas for which energy savings could be quantified:

1. Obtained data on the average amount of emissions of six different types (Carbon, $\mathrm{NO}_{\mathrm{x}}, \mathrm{SO}_{2}$, VOCs, CO, and PM10) associated with consumption of five different fuel types (electricity, natural gas, fuel oil, coal, and gasoline) from the GPRA Data Call 2003 (U.S. Department of Energy 2001b).

2. Converted emissions from the units given in the GPRA Data Call 2003 (usually, metric tons per trillion source BTUs) to metric tons per million source BTUs.

3. Obtained estimates of the fuel mix for each program area and, where relevant, for specific energy-consuming sectors (e.g., residential, commercial) within the broader program area, from the various sources used to develop per-unit energy-savings estimates.

4. For each program area (and energy-consuming sector, where relevant), calculated coefficients for weighted average emissions per million source BTUs for each type of emission. This was done by multiplying the portion of total fuel usage accounted for by each fuel by the number of metric tons of emissions per million BTUs for that fuel and summing the products for all fuels involved. This was done separately for each of the six emissions types.

5. For each responding state, multiplied the weighted average of emissions per million source BTUs by the number of millions of source BTUs saved. Separate calculations were conducted for each of the six emissions types. This procedure was followed for each program area where savings could be quantified and, where relevant, for specific energyconsuming sectors within those program areas.

6. For those program areas containing multiple energy-consuming sectors, summed each responding state's emissions reductions for all sectors to get each state's total reduction for the entire program area. Again, this was done separately for each emissions type.

7. For each program area, summed the emissions reductions for all responding states to get total reductions for all 20 states combined. Six different sets of calculations were performed to yield emissions reductions for all of the emissions types studied. 

ORNL/CON-487

\section{INTERNAL DISTRIBUTION}

1. L. G. Berry

2. M. A. Brown

3. W. G. Craddick

4. T. R. Curlee

5-22. M. T. Eady

23. J. F. Eisenberg

24. E. C. Fox

25. M. B. Gettings
26. S. G. Hildebrand

27. M. Martin

28. M. Schweitzer

29. R. B. Shelton

30. B. E. Tonn

31-33. ESD Library

34. ORNL Central Research Library

35. ORNL Laboratory Records-RC

\section{EXTERNAL DISTRIBUTION}

36. Mark L. Bailey, U.S. DOE, EE-2K, Room 5E-080, Office of the Weatherization and Intergovernmental Program, 1000 Independence Avenue, SW, Washington, DC 20585.

37. Daniel T. Beckley, U.S. DOE, EE-2K, Room 5E-098, Office of the Weatherization and Intergovernmental Program, 1000 Independence Avenue, SW, Washington, DC 20585.

38. Chris Benson, Arkansas Energy Office, One Capitol Mall, Little Rock, AR 72201

39. Paul DeCotis, NYSERDA, 17 Columbia Circle, Albany, NY 12203-6399.

40. Jerome Dion, U.S. DOE, EE-40, Room 5E-052, 1000 Independence Avenue, SW, Washington, DC 20585.

41. Jacob Fey, Washington State University Energy Program, 925 Plum Street, SE, Bldg. \# 4, P.O. Box 43165, Olympia, WA 98504-3165

42. Mike Forster, 401 Adams Avenue, Suite 560, Montgomery, AL 36103-5690.

43. Jeff Genzer, Duncan, Weinberg, Genzer, and Pembroke, 1615 M Street, NW, Suite 800, Washington, DC 20036.

44. Charles R. Grice, Governor's Office of Energy Management and Conservation, 225 East $16^{\text {th }}$ Avenue, Suite 650, Denver, CO 80203.

45. Nick Hall, TecMRKT Works, 165 Netherwood, Suite A, Oregon, WI 53575.

46. Tobin K. Harvey, U.S. DOE, EE-1, Room 6A-013, Office of the Assistant Secretary, 1000 Independence Avenue, SW, Washington, DC 20585.

47. John F. Herholdt, Jr., West Virginia Development Office, Bldg. 6, Room 645, State Capitol Complex, Charleston, WV 25305.

48. Robert W. Hoppie, Idaho Energy Division, 1301 N. Orchard Street, Boise, ID 83706.

49. William J. Keese, California Energy Commission, 1516 Ninth Street, MS \#32, Sacramento, CA 95814.

50. Faith S. Lambert, U.S. DOE, EE-2K, Room 5E-080, Office of the Weatherization and Intergovernmental Program, 1000 Independence Avenue, SW, Washington, DC 20585 
51. Randall Lamp, Tennessee Department of Economic and Community Development, 312 Eighth Street, North, $9^{\text {th }}$ Floor, Nashville, TN 37243-0405

52. Linda Limback, Minnesota Department of Commerce, $857^{\text {th }}$ Place East, Suite 500, St. Paul, MN 55101-2198.

53. Janice McClanaghan, Rhode Island State Energy Office, One Capitol Hill, Providence, RI 02908

54. Julia Miller, Georgia Environmental Facilities Authority, 2090 Equitable Building, 100 Peachtree Street, NW, Atlanta, GA 30303.

55-64. John P. Millhone, U.S. DOE, EE-2K, Office of the Weatherization and Intergovernmental Program, 1000 Independence Avenue, SW, Washington, DC 20585.

65. William P. Nesmith, Oregon Office of Energy, 625 Marion Street, NE, Salem, OR 97310.

66. John F. Nunley, III, Wyoming Business Council, 214 W. 15 ${ }^{\text {th }}$ Street, Cheyenne, WY 82002.

67. Jim O'Neal, Division of Energy and Public Benefits, 101 E. Wilson Street, $6^{\text {th }}$ Floor, P.O. Box 7868, Madison, WI 53707-7868

68. Elizabeth S. Raman, DBEDT-ERT Division, P.O. Box 2359, Honolulu, HI 96804.

69. P. Richard Rittelman, FAIA, Executive Vice President, Burt Hill Kosar Associates, 400 Morgan Center, Butler, PA 16001-5977.

70. Ronald V. Santoro, U.S. DOE, EE-2K, Room 5E-080, Office of the Weatherization and Intergovernmental Program, 1000 Independence Avenue, SW, Washington, DC 20585.

71. Gardner Sapp, 205A Legislative Office Building, 18 Capitol Square, Atlanta, GA 30334.

72. Ann Selzer, Nebraska Energy Office, P.O. Box 95085, 1111 “O” Street, Suite 223, Lincoln, NE 68509-5085.

73. Roya Stanley, State and Local Initiatives Team, NREL, 1617 Cole Blvd., Golden, CO 80401.

74. Sharon Tahtinen, Energy Bureau, Iowa Department of Natural Resources, Wallace State Office Building, East $9^{\text {th }}$ and Grande Avenue, Des Moines, IA 50319.

75. William E. Taylor, Texas Energy Conservation Office, 111 E. $17^{\text {th }}$ Street, $11^{\text {th }}$ Floor, Austin, TX 78701.

76. David Terry, NASEO, 1414 Prince Street, Suite 200, Alexandria, VA 22314.

77. Eric W. Thomas, U.S. DOE, EE-2K, Room 5E-080, Office of the Weatherization and Intergovernmental Program, 1000 Independence Avenue, SW, Washington, DC 20585.

78. Dr. Susan F. Tierney, The Economic Resource Group, Inc., One Mifflin Place, Cambridge, MA 02138.

79. Sara Ward, Ohio Department of Development, Office of Energy Efficiency, 77 S. High Street, $26^{\text {th }}$ Floor, P.O. Box 1001, Columbus, OH 43216-1001. 